\title{
Doğrulayıcı Faktör Analizi için Gerekli Örneklem Büyüklüğü Kaç Kişidir? : Bayes Yaklaşımı ve Maksimum Olabilirlik Kestirimi
}

\author{
DOI: $10.26466 /$ opus. 826895
}

\author{
* \\ Gizem Uyumaz ${ }^{*}$ - Gözde Sirganc1 ** \\ * Dr. Öğr. Üyesi, Giresun Üniversitesi, Eğitim Fakültesi, Giresun/Türkiye \\ E-Posta: gizemuyumaz@gmail.com \\ ORCID: $\underline{0000-0003-0792-2289}$ \\ ** Dr. Öğr. Üyesi, Yozgat Bozok Üniversitesi, Eğitim Fakültesi, Yozgat/Türkiye \\ E-Posta: gozdesirganci@gmail.com \\ ORCID: $\underline{0000-0003-4824-5413}$
}

\begin{abstract}
Öz
Bu çalışmanın öncelikli amacı özellikle sosyal bilimler ve eğitim bilimleri alanlarında çalışmalar yapan araştırmacılara, doğrulayıcı faktör analizinde (DFA) uygun sonuçlar elde edebilmek için gerekli örneklem büyüklü̈̆̈üyle ilgili kolay ulaşılabilir bir kaynak hazırlamaktır. Çalışmanın diğer amacı çeşitli koşullar altında küçük örneklemlerde, farklı faktör yükü ve faktörler arası korelasyon koşullarında, maksimum olabilirlik kestirimine ve bilgilendirici ve bilgilendirici olmayan önsellerin kullanılarak Bayes yaklaşımına dayalı olarak yapılan DFA ile elde edilen kestirimlerin kestirim yanlılığı, hata kareler ortalaması ve istatistiksel gücünün belirlenmesidir. Özellikle doğru tanımlanmış bilgilendirici önseller kullanılan Bayes DFA, tüm örneklem büyüklüklerinde en iyi performansı göstermektedir. Bilgilendirici önseller hatalı belirlendiğinde Bayes DFA daha düşük performans gösterir. Düşük faktör yüklerinde, önseller bilgilendirici olmasa bile Bayes kestirimi maksimum olabilirlik kestiriminden daha az yanl sonuçlar verir. Zayıf faktör yükleri koşulunda tahminler, özellikle (çok) küçük örneklem büyüklüklerinde $(N=50$ veya daha az) kestirimleri gerçek değerinden yüksek yapma eğilimindedir. Bayes DFA, özellikle daha küçük örneklem büyüklüklerinde, düşük faktör yüklerinde maksimum olabilirlik DFA'dan daha iyi performans gösterir. Faktör yükleriyle ilgili önseller bilgilendirici ise Bayes DFA, daha düşük örneklem büyüklüklerinde maksimum olabilirlik DFA'dan daha az yanl sonuçlar verir. Maksimum olabilirlik kestirimlerinde, düşük örneklem büyüklüklerinde ve zayıf ile orta faktör yüklerinde sorunlarla karşılaşılırken, Bayes DFA sürekli olarak hatasız çalışır.
\end{abstract}

Anahtar Kelimeler: yapısal eşitlik modeli, bayesçi yaklaşım, küçük örneklemler, monte carlo simülasyonu. 


\title{
What is the Required Sample Size for Confirmatory Factor Analysis?: Bayesian Approach and Maximum Likelihood Estimation
}

\begin{abstract}
The primary aim of this study is to prepare an easily accessible resource about the sample size necessary for researchers working in the fields of social and educational sciences to obtain appropriate results in confirmatory factor analysis (CFA). The other aim is to determine the prediction bias, mean square error and statistical power of the predictions obtained by the confirmatory factor analysis based on Bayesian approach using informative and non-informative a priori in small samples under various conditions, different factor loadings and correlation conditions between factors. determination. Especially the informative priors perform well, and this at all sample sizes and also Bayesian CFA performs less well when the informative priors are miss specified. Bayesian CFA performs better than ML-CFA when the factor loadings are weak, even with a diffuse prior. With weak factor loadings, the estimates are biased upwards, especially at (very) small sample sizes ( $N=50$ or less). Bayesian $C F A$ performs better than $M L$ CFA at low factor loadings, especially at smaller sample sizes. Bayesian CFA does better at lower sample sizes, if the priors on the factor loadings are informative. While ML-CFA runs into problems at low sample sizes and weak to moderate factor loadings, Bayesian CFA consistently runs without errors.
\end{abstract}

Keywords: structural equation model, bayesian approach, small sample, monte carlo simulation. 


\section{Giriş}

Faktör analizi, ölçek maddelerine verilen yanttlardan oluşan veri matrisindeki içsel ilişkiler analiz edilerek altta yatan psikolojik yapının ortaya çıarılmasının amaçlandığı çok değişkenli istatistiksel tekniklerin genel adıdır (Hair, Anderson, Tatham ve Black, 1998). Faktör analizi, araştırmalarda açımlama ve doğrulama olmak üzere iki amaçla kullanılabilir. Açımlayıcı faktör analizi (AFA) değişkenler arasındaki ortak gizil yapıyı ortaya çıkarmak ve olası kuramsal yapıyı görmek için, DFA ise gizil yapıyla ilgili önceki araştırmalara/kuramlara dayalı hipotezleri test etmek ve yapının desteklenip desteklenmediğine ilişkin deneysel kanıt oluşturmak için kullanılır (Goodwin, 1999). Araştırmacıların çoğu çalışması kapsamında topladıkları verilerin geçerliğini test etmek amacıyla hangi faktör analizini yapması gerektiğini belirlemede sıkıntı yaşamaktadır. Buradan yola çıkılarak; AFA yalnızca ölçek geliştirme çalışmasında gizil yapıyı ortaya çıkarmak için ölçeği geliştiren kişiler tarafından yapılır. Geliştirilmiş bir ölçeği kendi çalışmasında kullanacak araştırmacılar ile bu ölçeği kendi kültürüne uyarlayacak olan araştırmacılar, geliştiren araştırmacıların ortaya koyduğu yapının kendi çalışmalarında toplanan verilerle desteklenip desteklenmediğine kanıt oluşturmak için DFA yapmalıdir.

İstatistiksel modellemenin avantajları, ilgili yazılım ve programların kullanımının kolaylığı, hem gizil değişkenlerin analiz edildiği çalışmaların sayısinda hem de bu tarz modellerin test edilmesinde gerekli olan örneklem büyüklügünün nasıl belirleneceği sorusunda artış sağlamıştır. Yapısal Eşitlik Modeli (YEM) karmaşık ilişkilerin incelenmesi, farklı tipteki verilerin kullanımı ve alternatif modellerin karşılaştırılması konularında esnek olan güçlü bir tekniktir (Wolf, Harrington, Clark ve Miller, 2013). YEM'in bu özellikleri gerekli olan örneklem büyüklügünün belirlenmesine ilişkin genellemeleri zorlaştırmaktadır (MacCallum, Widaman, Zhang ve Hong, 1999). Araştırmacıların çoğu çalışması kapsamında DFA yapmak için kaç kişilik bir gruba ulaşması gerektiğini sormaktadır. Fakat tüm çalışmalarda kullanılabilecek bir kural bulunmamaktadır, çünkü ulaşılması gereken örneklem büyüklüğü pek çok faktöre bağlıdır.

Alanyazın incelendiğinde pek çok kaynakta DFA için gerekli örneklem büyüklüğüne ilişkin bilgiler yer almaktadır. Gerekli örneklem büyüklügünü 
bir grup araştırmacı kişi sayısı temelinde ele almıştır. Bu çalışmalarda; örneklem büyüklüğünün 100'den büyük olması gerektiği (Anderson ve Gerbing, 1984), en az 100-200 kişi gerektiği (Boomsma, 1982; 1985), 200-400 arasında olması gerektiği (Jackson, 2001), normal dağılmayan sürekli değişkenler için örneklem büyüklüğünün 250'den büyük olması gerektiği (Hu ve Bentler, 1999; Yu ve Muthén, 2002) raporlanmıştır. Comrey ve Lee (1992) 300 kişilik örneklem büyüklüğünü “iyi”, 500 kişilik örneklem büyüklügünü "çok iyi” ve 1000 kişilik örneklem büyüklüğünü ise "mükemmel" olarak belirtmektedir. Bazı araştırmacılar gerekli örneklem büyüklüğünü değişken sayısı ya da madde sayısı temelinde ele almıştır. Cohen ve Cohen (1983) her değişken için minimum 10 katılımcı, Muthén ve Muthén (2002) değişken başına 50-100 katılımc1, Stevens (2002) ölçekte yer alan her bir madde için 5-20 arasında değişen katılımcı önermektedir. Goodwin (1999) ise sahip olunması gereken en az katılımcı sayısını, değişken sayısının 3 katı ile başlatmakta ve 50 katına kadar varan geniş bir ranj tanımlanmaktadır. Modeldeki serbest parametre sayısının 5 katı kadar (Tanaka, 1987), serbest parametre sayısının 10 katı kadar (Jöreskog ve Sörbom, 1996), parameter sayısının 5-10 katı kadar (Bentler ve Chou, 1987; Bollen, 1989; Muthén ve Muthén, 2002) katılımcı olması gerektiğini belirten araştırmalar mevcuttur. İlk çalışmalarda DFA için genellikle en az 200, 250 ve 500 kişilik örneklem büyüklüklerine ya da değişken sayısının 3, 6, 20 katı kadar kişiye ulaşılması gerektiği belirtilmiştir (De Winter, Dodou ve Wieringa, 2009). Sonraki çalışmalarda ise faktörde yer alan madde sayısı, faktör yükleri, faktör sayısı, modelin büyüklüğü, değiş̧kenlerin dağılımı (verinin dağılımının normalliği), kayıp veri miktarı, güvenirlik, değişkenler arası ilişkiler, faktör çapraz yükleri (factor cross-loadings), artık kovaryanslar ve grubun özellikleri (De Winter vd., 2009; Muthén ve Muthén, 2002) gibi farklı değişkenlerin de göz önünde bulundurulması gerektiği vurgulanmaya başlanmıştır.

Örneklem büyüklüğünün ne kadar olması gerektiği sorusunun cevabı için farklı araştırmacılar tarafından yürütülen benzetim (simülasyon) çalışmaları bazı yaklaşık sayılar sunmaktadır ancak bunlar her duruma uygun olmayabilir, bu nedenle de kesin bilgi olarak alınmamalıdır. Çünkü benzetim çalışmaları belli özel koşullar altında gerçekleştirilmektedir. De Winter ve arkadaşları (2009) yaptıkları benzetim çalışmasında, faktör yüklerinin yüksek, modeldeki faktör sayısının düşük ve gözlenen değişken sayısının yüksek ol- 
duğu durumlarda 50 kişiden düşük örneklem büyüklüklerinin bile yeterli olduğunu raporlamıştır. Örneğin faktör yükleri 0,60 olan 6 gözlenen değişkenli (maddeli) tek faktörlü model, 18 kişilik örneklem büyüklügünde uygun değerlere ulaşmıştır. Nevitt ve Hancock (2004) ise yaptıkları çalışmada modelin karmaşıklığının örneklem büyüklüğünün belirlenmesi açısından önemli olduğunu vurgulamıştır. Bu nedenle 10 katı kuralı 5 katı kuralına göre daha uygun görülmektedir ancak bunun da yeterli olmadığ durumlar bulunmaktadır. Normal dağılıma uygun olmayan sürekli değişkenlerle yaptıkları bootstrap çalışmasında 200-1000 arasındaki örneklem büyüklüklerinde uygun sonuçlara ulaşılmıştır. Uyum, modelin karmaşıklığına bağlıdır. Çok basit modellerde 100 kişi yeterli olabilir. Kestirimlerin doğruluğu açısından çalışmalarda 250'den fazla bootstrap örneklemin kullanılması önerilmiştir.

DFA'da ulaşılması gereken örneklem büyüklügünün belli bir kişi sayısı olarak ya da değişken sayısının belli bir katı olarak ifade edilmesi, model temelli olmadığından ve kestirimlerin gerçek değerinden düşük ya da yüksek yapılması problemine açık olabileceğinden sorunludur. Bu tür örneklem büyüklüğü belirleme yaklaşımları hızlı ve kullanışı olabilir fakat uygun değildir (Wolf vd., 2013). DFA için gereken örneklem büyüklüğünün belirlenmesi için önerilen kişi sayısının serbest parametrelere oranı (N/q oranı) kuralı; minimum örneklem büyüklüğü (>200-400) ve standardize edilmiş yüklerin büyüklüğü (örneğin, >.60) gibi diğer faktörler kadar önemli olmayabilir (Jackson, 2001). MacCallum vd. (1999) YEM'de değişkenler arasındaki ilişki düzeyi, örneklem büyüklügü ve faktör belirleme derecesi gibi model özelliklerinin hepsinin parametre tahminlerinin ve model uyumu istatistiklerinin doğruluğunu etkilediğini, bu nedenle de örneklem büyüklüğü kurallarının uygulanmasının yeterliliği ile ilgili şüphelerin arttığını göstermiştir. Modelin yanlış tanımlanıp tanımlanmadığı yani gerçek modelin test edilenden farklı olup olmadığı da örneklem büyüklüğü açısından kritiktir. Mutlak uyum indeksleri (Ki-kare, RMSEA vb.) modelin yanlış tanımlanmasına karşı, göreceli uyum indekslerinden (CFI vb.) daha duyarlıdır. Hu ve Bentler (1999), örneklem büyüklüğü 250'den küçük veya 250'ye eşitse, modelleri aşırı reddetme eğiliminde olunabileceği için mutlak ve göreceli uyum indekslerinin bir arada kullanılmasını öne sürmüşlerdir. Örneklem büyüklügünün belirlenmesinde basit bir kural yoktur; uyum indeksleri, standardize edilmiş yükler, hatalı tanımlama durumu ve N/q oranı birlikte değerlendirilmelidir (Jackson, 2001). 
YEM'de örneklem büyüklüğünün belirlenmesi için önerilen üç temel yaklaşım vardır; (1) Satorra ve Saris'in 1985 yılında önerdiği, güç kestiriminin modelin yanlış tanımlanması miktarı vb. merkezi olmayan parametrelere dayanan yöntem, (2) MacCallum, Browne ve Sugawara'nın 1996'da önerdiği, iyi model uyumu ile tutarlı olan RMSEA değeri kestirimine sahip modelin gücüne dayanan yöntem (Wolf vd., 2013), (3) Monte Carlo benzetim yöntemi (Muthén ve Muthén, 2002). Bu çalışmada kullanılan Monte Carlo benzetim yöntemi ile değişkenler arası ilişkiler önsel hipotezlere dayalı olarak araştırmacılar tarafından belirlenir. Tanımlanan ilişkiler, değişkenler arasındaki gerçek ilişkilerin popülasyon tahminlerine benzer. Daha sonra, popülasyon değerleriyle eşleşecek çok sayida veri kümesi oluşturulur; her bir veri seti bir örneğe benzer ve araştırmacılar tarafından belirlenen sayıda koşula dayanır. Varsayılan model daha sonra üretilen veri setlerinde değerlendirilir ve her bir parametre tahmininin, belirtilen koşul sayısının popülasyon değerlerini yeniden oluşturmak ve istatistiksel olarak anlamlı parametre tahminlerini elde etmek için yeterli olup olmadığını belirlemek için benzetimler boyunca ortalaması alınır. Bu yaklaşım modelin gücünü vermez, güç ve yanlılık için faktör yükleri, korelasyonlar, regresyon yolları vb. kestirimleri sağlar (Wolf vd., 2013).

Örneklem büyüklügüüne karar verirken dikkate alınması gereken diğer konu güçtür. Örneklem büyüklüğü; yansız parametre kestirimleri, yansız standart hata kestirimleri ve iyi bir kapsama (coverage) için yeterli büyüklükte olabilir ancak modeldeki önemli etkileri belirlemek için yeterli büyüklükte olmayabilir. DFA'da gücün belirlenmesinde odak faktör korelasyonudur. Çünkü faktör korelasyonu, ölçme hatası tarafından zayıflatılamayan yani ölçüm hatasından etkilenmeyen iki yapı arasındaki ilişkiyi temsil eder (Bandalos 2006; Muthén ve Muthén, 2002). İstatistiksel test, parametre kestiriminin standart hatasına oranıdır ve büyük örneklemlerde yaklaşık olarak normal dağılır. Sıfırdan farklı popülasyon değerleri olan parametreler için, bu değer gücün bir kestirimidir yani yanlış olan yokluk hipotezinin reddedilme olasılığıdır (2. Tip hata yapmama olasılığıdır, 1- $\beta$ ). Sıfıra eşit popülasyon değerleri için bu değer 1. tip hata kestirimidir yani doğru olan yokluk hipotezinin reddedilme olasılığıdır (Cohen, 1988; Muthén ve Muthén, 2002). Güç; 1) seçilen alfa düzeyine (genellikle $\alpha=.05$ ), 2) ilgilenilen etki büyüklüğüne ve 3) örneklem büyüklüğüne bağlıdır. Bununla birlikte, parametre tahminlerindeki sapma ve standart hataların da etkisi olduğundan, örneklem 
büyüklüğünü belirlemede güç tek husus değildir. Sapma, tahmini bir parametre değerinin gerçek popülasyon değerinden farklı olduğu koşulları ifade eder (Kelley ve Maxwell, 2003; Maxwell, Kelley ve Rausch, 2008). Standart hata, olduğundan düşük veya fazla kestirilmesi durumunda da yanlı olabilir, bu durumlar sırasıyla I. Tip ve II Tip hata riskini artırır (Wolf vd., 2013).

Örneklem büyüklüğü yeteri kadar yüksek olduğunda, istatistiksel testler için gerekli güç düzeyine ulaşılabilir (Hancock ve French, 2013). Ancak Wolf ve arkadaşları (2013) yaptıkları çalışmada "Güç yeterli değildir.” şeklinde ifade ederek, örneklem büyüklüğ̈ünün belirlenmesinde sadece güce bakmanın nasıl problemli olabileceğini göstermiştir. Denenen pek çok modelde istatistiksel gücün yanında, yanlılık ve hatalar da örneklem büyüklüğünü etkilemektedir.

Bu çalışmanın öncelikli amacı özellikle sosyal bilimler ve eğitim bilimleri alanlarında çalışmalar yapan araştırmacılara, DFA'da uygun sonuçlar elde edebilmek için gerekli örneklem büyüklüğüyle ilgili kolay ulaşılabilir bir kaynak hazırlamaktır. Çalışmanın diğer amacı ise çeşitli koşullar altında küçük örneklemlerde, farklı faktör yükü ve faktörler arası korelasyon koşullarında, maksimum olabilirlik kestirimine ve bilgilendirici ve bilgilendirici olmayan önsellerin kullanılarak Bayes yaklaşımına dayalı olarak yapılan DFA ile elde edilen kestirimlerin kestirim yanlılığı, hata kareler ortalaması ve istatistiksel gücünün belirlenmesidir. Bu amaç doğrultusunda aşağıdaki sorulara yanıt aranmıştır;

Doğrulayıcı faktör analizinde;

1. Örneklem büyüklüğü $(25,50,100,200)$,

2. Faktör yükü $(0.40,0.60,0.80)$,

3. Faktörler arası korelasyon $(\mathrm{r}=0.30, \mathrm{r}=0.50)$,

4. Kestirim tipi (Bayes, maksimum olabilirlik),

5. Önselin türü (bilgilendirici, bilgilendirici olmayan) ve

6. Önselin tanımlanma şekli (hatalı, doğru)

elde edilen kestirimlerin kestirim yanlılığını, hata kareler ortalamasını ve istatistiksel gücünü nasıl farklılaştırmaktadır?

\section{Yöntem}

Doğrulayıcı faktör analizi ile elde edilen kestirimlerin kestirim yanlılığı, hata kareler ortalaması ve istatistiksel gücünün belirlenmesinin amaçlandığı bu 
çalışmada; bilgilendirici ve bilgilendirici olmayan önsellerin kullanıldığı Bayes yaklaşımı ve maksimum olabilirlik kestirimi kullanılmıştır.

Geleneksel olarak frekans tabanlı maksimum olabilirlik kestirimine dayalı YEM yerini son zamanlarda popüleritesi artan Bayes yaklaşımına dayalı kestirim yöntemlerine bırakmıştır. Bayes istatistikleri Bayes' in koşullu olasıllk ilkesine dayanmaktadır. Bayes yaklaşımında önsel dağılımlar ve olabilirlik dağılımının çarpılması sonucu sonsal dağılımlar kestirilir. Bayes yaklaşımına dayalı yöntemler maksimum olabilirlik gibi frekans kestirim tekniğine dayalı yöntemlere kıyasla bir dizi avantaja sahiptir. Öncelikle maksimum olabilirlik kestirimine dayalı yapısal eşitlik modelleri büyük örneklem teorisine dayanır ve büyük örneklemlerde ( $\mathrm{N}=200$ veya fazlası) kullanılması önerilmektedir (Muthén ve Asparouhov, 2012; Song ve Lee, 2012). Bu yöntemler, kovaryans yapısının hesaplanmasının zor olduğu durumlarda, veri yapısının kompleks olduğu durumlarda, küçük örneklemlerde modelin yakınsamaması, negatif artık varyansların olması gibi problemli sonuçlara yol açmaktadır (Heerwegh, 2014; Song ve Lee, 2012). Bayes yaklaşımına dayalı yapısal eşitlik modelleri ise büyük örneklem teorisine dayalı değildir ve bu yöntemler ile küçük örneklemlerde daha az yanlı kestirimler elde edilir. Dolayısıyla küçük örneklemlere dayalı çalışmalarda daha kullanışlıdırlar (Muthén ve Asparouhov, 2012). Bayes yaklaşımına dayalı yöntemlerin bir diğer avantajı ise bu yaklaşımların temelde aynı yokluk hipotezini tekrar tekrar test etmek yerine önsel bilgileri analizlere dahil etmesidir. Bayes yaklaşımına dayalı YEM'de araştırmacılar belirli bir parametre için bilgilendirici olmayan (geniş varyanslı) önsel dağılımlar veya bilgilendirici (küçük varyanslı) önsel dağılımlar kullanabilirler (Heerwegh, 2014; Song ve Lee, 2012). Geniş varyanslı önsellerin kullanılması durumunda parametrelerin sonsal dağılımları büyük ölçüde veri setinden kestirilirken, küçük varyanslı önsellerin kullanımı parametrelerin sonsal dağılımlarının kestiriminde veri seti ve önsellerin kombinasyonunun kullanılmasına olanak sağlar. Örneklem büyüklüğü ve önselin ne derece bilgilendirici olduğu parametrelerin sonsal dağılımının kestirimini etkiler (Van de Schoot, Kaplan, Denissen, Asendorpf, Neyer ve Van Aken, 2014). Bayes yaklaşımına dayalı YEM'de geniş varyanslı önseller kullanıldığında maksimum olabilirlik ile yapılan kestirimlerin sonuçları birbirine yakınlık göstermektedir. Diğer bir ifade ile büyük örneklemlerde geniş varyanslı önsellerin kullanılması durumunda olabilirlik fonksiyonu üzerinde sonsal dağılımların daha büyük bir etkisi olduğu görülmektedir. Tersine örneklem büyüklüğü 
azaldıkça, önsellerin sonsal dağılımlar üzerindeki etkisinin arttığı görülmektedir. Bu doğrultuda küçük örneklemlerde kullanılacak olan uygun önsel dağılımların belirlenmesi yansız kestirim yapılması açısından önem taşımaktadır. Bayes yöntemlerinin bir diğer avantajı model tanımlanması ile ilgilidir. Geleneksel tahmin yöntemleri, bir modelin tanımlanmasını gerektirir. Örneğin, kovaryans tabanlı yöntemlerde, tüm çapraz yüklemelerin serbest parametreler olduğu bir DFA modelini tahmin etmek imkansızdır. Bayes yaklaşmına dayalı tahmin, eğer önsel parametre dağılımı değerleri yeterince kısıtlandıysa, araştırmacıların tanımlanmamış modelleri tahmin etmelerini sağlar. Örneğin, yaklaşık sıfır olması beklenen çapraz yük değerli DFA modellerini tahmin etmek mümkündür. Eğer araştırmacı çapraz yük değerleri ile ilgili teorik beklentilere sahipse bu tür modellerin kullanılmasının daha uygun olduğu savunulmaktadır. Alanyazında, Bayes yaklaşımına dayalı DFA'nın performansının belirlenmesine ilişkin bazı benzetim çalışmalarının yapıldığı (Asparouhov ve Muthén, 2010; Helm, Castro-Schilo ve Oravecz, 2017) görülmektedir. Ancak alanyazında çok küçük örneklemler gibi spesifik durumlarda model performansının değerlendirildiği bir çalışmaya (Heerwegh, 2014) rastlanmıştır.

\section{Benzetim Koşulları}

Bu çalışmada Bayes yaklaşımına ve maksimum olabilirlik kestirimine dayalı DFA, her biri üç gösterge değişkenden oluşan iki faktörlü DFA modeli temel alınarak karşılaştırılmıştır.

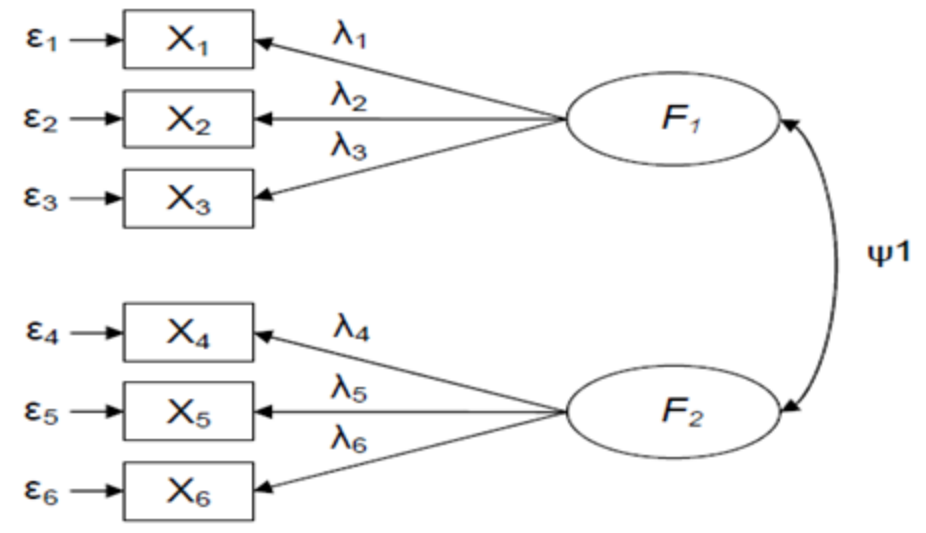


Araştırmanın benzetim koşullarını: 1) küçük örneklemi temsil eden dört farklı örneklem büyüklüğü $(25,50,100,200)$; 2) yüksek, orta ve düşük dereceyi temsil eden üç farklı standardize edilmiş $[-1,1]$ faktör yükü $(0.40,0.60$, $0.80)$; 3) zayıf ve güçlü korelasyonu temsil eden iki farklı faktörler arası korelasyon ( $\mathrm{r}=0.30, \mathrm{r}=0.50)$; 4 ) Bayes yaklaşımına dayanan bilgilendirici olmayan $\mathrm{N}(0, \infty)$ bir önsel dağılım, Bayes yaklaşımına dayanan bilgilendirici $[\mathrm{N}(0.40$, $0.05)$ ve $\mathrm{N}(0.40,0.01)]$ iki farklı önsel dağılım ve maksimum olabilirlik olmak üzere dört farklı kestirim oluşturmaktadır.

Araştırmanın sabit koşulları olarak; parameter değerlerini daha kolay yorumlanabilir hale getirdiği için (Muthén ve Muthén, 2002) faktör varyansları 1 , artık varyanslar 0.36 değerine kısıtlanmıştır. Altı faktör yük değeri her bir benzetim koşulunda eşit değere (ilk grup koşulda tüm faktör yük değerleri 0.40 , diğer bir grup koşulda tüm faktör yük değerleri 0.60 , son grup koşulda tüm faktör yük değerleri 0.80) kısıtlanmıştır. Gerçek faktör yüklerinin 0.80 ve 0.60 olduğu durumlar için önseller hatalı tanımlanmış (miss specified) olmaktadır. Araştırmada $96(4 \times 3 \times 2 \times 4)$ Monte Carlo benzetimi ile çalışılmıştır.

\section{Verilerin Analizi}

Monte carlo benzetim yöntemi için MPlus versiyon 7 kullanılmıştır. Her bir analiz için 1000 yineleme (replikasyon) gerçekleştirilmiştir. Yineleme sayısına karar verirken sonuçların kararlılığa ulaşma durumu dikkate alınmıştır.

Çalışma kapsamında değerlendirme kriterleri olarak parametre kestirim yanlılığ $1(\%)$, hata kareler ortalaması ve istatistiksel güç güç kullanılmıştır. Parametre kestirim yanlılığ1 yüzde ile ifade edilir (Bandalos 2006) ve 1000 yineleme sonucunda kestirilen faktör yük değerlerinin modelde yer alan 6 madde için ortalaması ile popülasyonun gerçek değerinin farkının, popülasyon değerine bölümünün 100 ile çarpılmasılla hesaplanır. Örneğin faktör yükünün 0.80 olduğu koşul için 6 faktör yükünün kestirilen değerinin ortalaması 0.85 olsun, parametre kestirim yanlılığ1 \%6.25 (100(0.85-0.80)/0.80) olacaktır (Heerwegh, 2014; Muthén ve Muthén, 2002). Parametre kestirimleri genellikle bir miktar yanlılık içermesine rağmen standart hatalar daha duyarlıdır. Farklı durumlara bağlı olarak olduğundan daha yüksek ya da düşük kestirilebilirler. Bu da kapsama (coverage olarak adlandırılan güven aralığını etkiler. Standart hata yüksek kestirilirse anlamlı etkiler kaçırılabilir, düşük kesti- 
rilirse anlamlı etkiler abartılabilir (Muthén ve Muthén, 2002). Hata kareler ortalamas1, Monte Carlo benzetiminde 1000 yinelemeden kestirilen varyans değerleri ile yanlılı̆̆ın karesinin toplanmasıyla hesaplanır (Muthén ve Muthén, 2002). Yanlılık, kestirilen değerlerin ortalaması ile gerçek (popülasyon) değerinin farkıdır (Heerwegh, 2014). Her bir faktör yükü için ve faktörler arası korelasyon (yani her parametre) için MPlus tarafından hesaplanır. Faktör yükleri için 6 değerin ortalaması alınır, faktörler arası korelasyon için tek değer vardır. İstatistiksel güç, her bir yineleme sonucunda, 0.05 düzeyinde, her bir parametrenin sıfıra eşit olduğunu varsayan yokluk hipotezinin reddedilme oranını verir (Heerwegh, 2014; Muthén ve Muthén, 2002).

\section{Bulgular}

\section{Parametre Kestirim Yanlılı̆̆ına İlişkin Bulgular}

Faktör Yüklerinin Parametre Kestirim Yanlılı̆̆ıa İlişkin Bulgular: Her bir örneklem büyüklüğü ( $\mathrm{N}=25, \mathrm{~N}=50, \mathrm{~N}=100, \mathrm{~N}=200$ ) için, faktörler arası korelasyon zayıf ( $\mathrm{r}=0.30$ ) olduğu durumdaki faktör yüklerinin parametre kestirim yanlılığına ilişkin bulgular Şekil 1'de, faktörler arası korelasyon güçlü ( $\mathrm{r}=0.50)$ olduğu durumdaki faktör yüklerinin parametre kestirim yanlılığına ilişkin bulgular Şekil 2'de verilmiştir.

Şekil 1 ve Şekil 2 birlikte incelendiğinde, hem zayıf hem de güçlü faktörler arası korelasyon koşulunda örneklem büyüklüğü arttıkça her bir yöntem için faktör yüklerinin parametre kestirim yanlılığı azalmaktadır.

Faktör yükünün 0.80 olduğu durumlarda: Her örneklem büyüklügünde ve faktörler arası korelasyonun hem zayıf hem de güçlü olduğu koşulda, kestirim yanlılığı en küçükten en büyüğe maksimum olabilirlik, bilgilendirici olmayan $\mathrm{N}(0, \infty)$ Bayes, bilgilendirici $\mathrm{N}(0.40,0.05)$ Bayes, bilgilendirici $\mathrm{N}(0.40$, 0.01) Bayes şeklindedir. Gerçek değere en yakın sonuçları maksimum olabilirlik kestirimi vermiştir. Bilgilendirici olmayan Bayes ile yapılan kestirim gerçek değerinden yüksek (over estimate), diğer yöntemlerle yapılan kestirimler gerçek değerinden düşük (under estimate) kestirilmiştir. 
Faktör Yükü:0.8, r=0.3
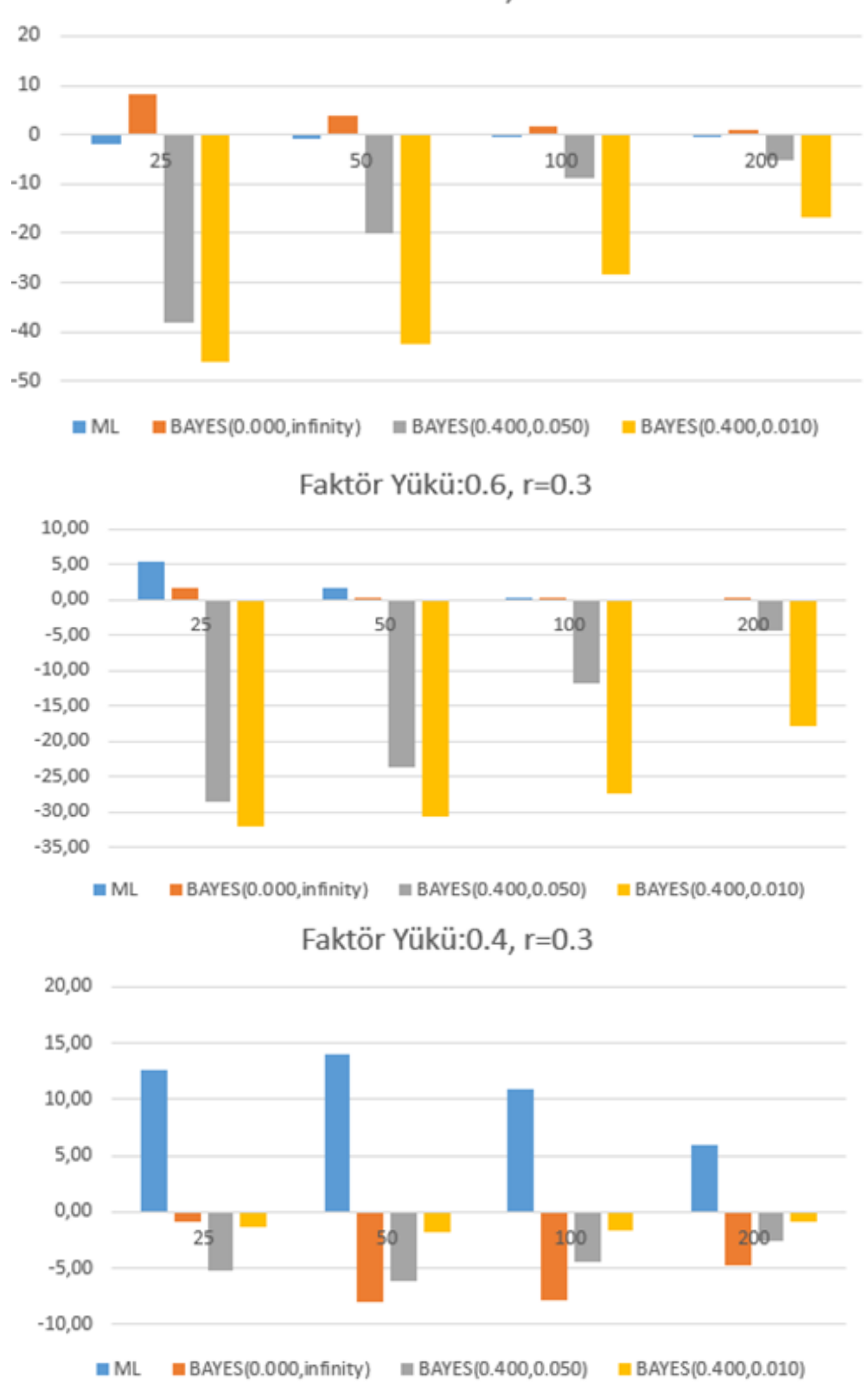

Şekil 1. Faktörler arası korelasyonun zayıf olduğu durumda her bir örneklem büyüklüğ̈̈ için faktör yüklerinin parametre kestirim yanlılı̆̆ 
Faktör Yükü:0.8, r=0.5

20

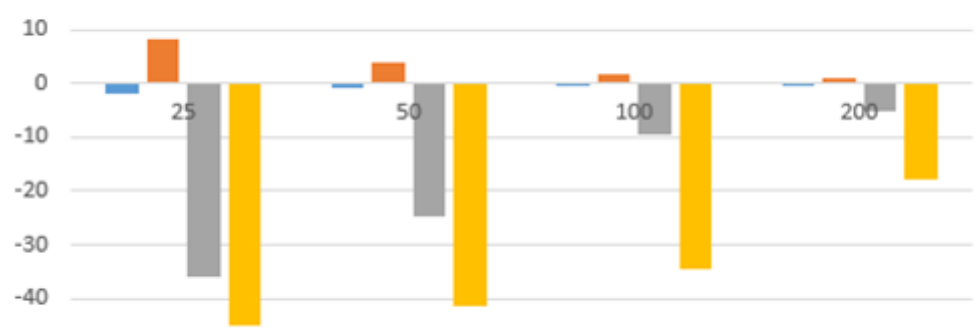

$-50$

$\equiv M L=\operatorname{BAYES}(0.000$, infinity) $\equiv \operatorname{BAYES}(0.400,0.050) \quad m \operatorname{BAYES}(0.400,0.010)$

Faktör Yükü:0.6, r=0.5

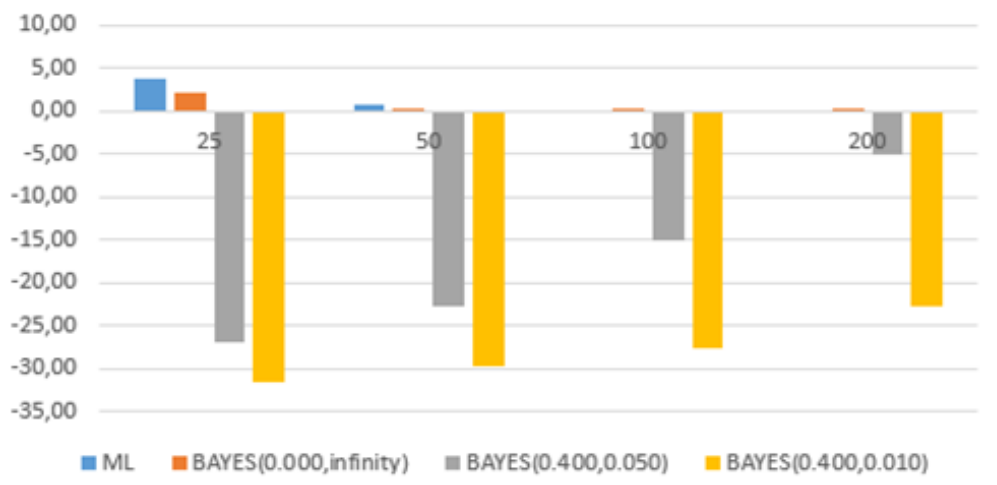

Faktör Yükü: 0.4, r=0.5

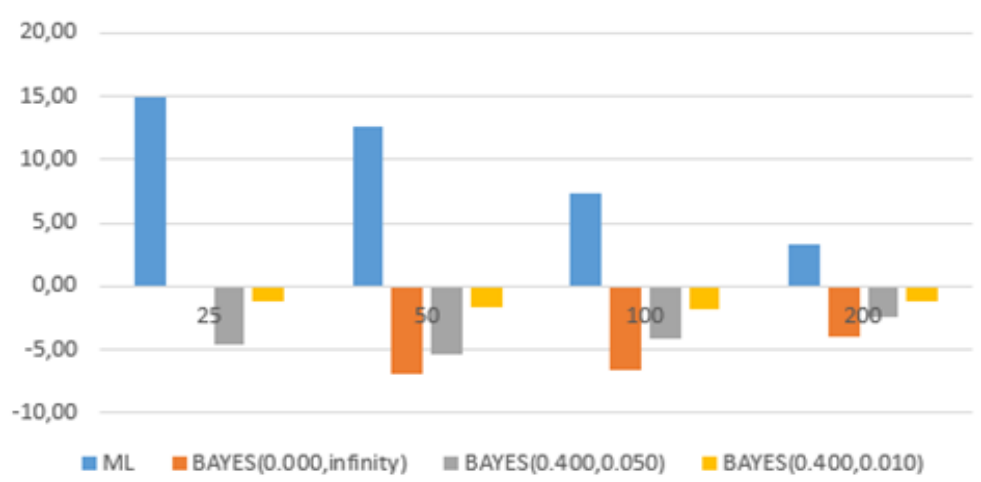

Şekil 2. Faktörler arası korelasyonun güçlï olduğu durumda her bir örneklem büyyüklï̆̈̈i için faktör yüklerinin parametre kestirim yanlılı̆̆ 
Faktör yükünün 0.60 olduğu durumlarda: Her örneklem büyüklügünde ve faktörler arası korelasyonun hem zayıf hem de güçlü olduğu koşulda, kestirim yanlılığı en küçükten en büyüğe bilgilendirici olmayan $\mathrm{N}(0, \infty)$ Bayes, maksimum olabilirlik, bilgilendirici $\mathrm{N}(0.40,0.05)$ Bayes, bilgilendirici $\mathrm{N}(0.40$, 0.01) Bayes şeklindedir. Gerçek değere en yakın sonuçları bilgilendirici olmayan Bayes kestirimi vermiştir. Bilgilendirici olmayan Bayes ve maksimum olabilirlik ile yapılan kestirim gerçek değerinden yüksek, diğer yöntemlerle yapılan kestirimler gerçek değerinden düşük kestirilmiştir.

Faktör yüklerinin 0.40 olduğu durumda, örneklem büyüklüğü $\mathrm{N}=50$, $\mathrm{N}=100$ ve $\mathrm{N}=200$ için kestirim yanlılı̆̆ en küçükten en büyüğe bilgilendirici $\mathrm{N}(0.40,0.01)$ Bayes, bilgilendirici $\mathrm{N}(0.40,0.05)$ Bayes, bilgilendirici olmayan $\mathrm{N}(0, \infty)$ Bayes, maksimum olabilirlik şeklindedir. Gerçek değere en yakın sonuçları bilgilendirici $\mathrm{N}(0.40,0.01)$ Bayes kestirimi vermiştir. 25 kişilik örneklemde ise kestirim yanlılığ 1 en küçükten en büyüğe bilgilendirici olmayan $\mathrm{N}(0, \infty)$ Bayes, bilgilendirici $\mathrm{N}(0.40,0.01)$ Bayes, bilgilendirici $\mathrm{N}(0.40,0.05)$ Bayes, maksimum olabilirlik şeklindedir. Gerçek değere en yakın sonuçları bilgilendirici olmayan Bayes vermiştir.

\section{Faktörler Arası Korelasyon Parametre Kestirim Yanlılı̆̆ına İlişkin Bulgular}

Her bir örneklem büyüklüğ̈̈ ( $N=25, N=50, N=100, N=200$ ) için, faktörler aras1 korelasyonun zayıf ( $\mathrm{r}=0.30$ ) olduğu durumdaki faktörler arası korelasyon parametre kestirim yanlılığına ilişkin bulgular Şekil 3'de, faktörler arası korelasyonun güçlü (r=0.50) olduğu durumdaki faktörler arası korelasyon parametre kestirim yanlılı̆̆ına ilişkin bulgular Şekil 4'de verilmiştir.

Şekil 3 ve Şekil 4 birlikte incelendiğinde, hem zayıf hem de güçlü faktörler arası korelasyon koşulunda örneklem büyüklügü arttıkça her bir yöntem için faktörler arası korelasyon parametre kestirim yanlılı̆̆ azalmaktadır. 25 kişilik düşük faktörler arası korelasyon, yüksek ve orta faktör yükü koşulları hariç kestirimler gerçek değerinden yüksek kestirilmiştir. 
Gizem Uyumaz - Gözde Sirgancı

Faktör Yükü :0.8, r=0.30

140

120

100

80

60

40

20

$-20$

40

$=\mathrm{ML} \equiv \mathrm{BAYES}(0.000$, infinity $) \quad \mathrm{BAYES}(0.400,0.050)=\mathrm{BAYES}(0.400,0.010)$

Faktör yükü:0.6, $r=30$

150

100

50

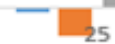

50

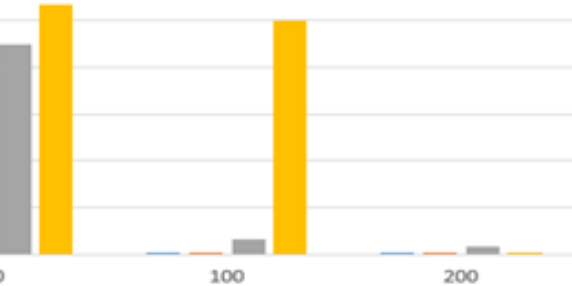

50

$-50$

= ML $=\operatorname{BAYES}(0.000$, infinity) $=\operatorname{BAYES}(0.400,0.050) \quad \mathrm{BAYES}(0.400,0.010)$

Faktör Yükü:0.4, r=30

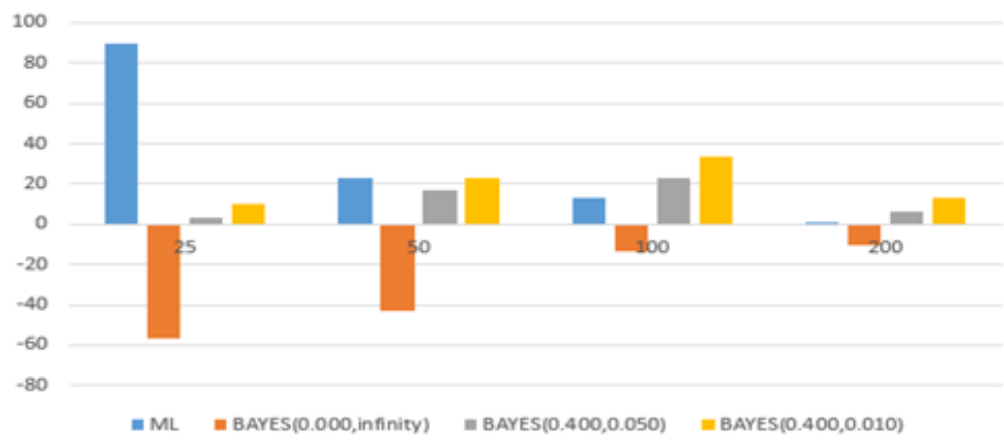

Şekil 3. Faktörler arası korelasyon zayıf olduğu durumda her bir örneklem büyükliü̆̈̈ için faktörler arası korelasyonun parametre kestirim yanlliğı 


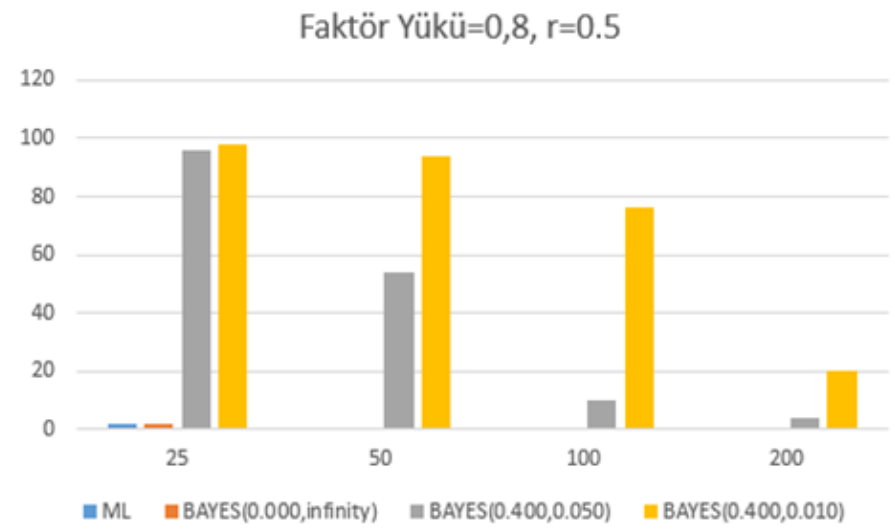

Faktör Yükü:0.6, r=.0.5

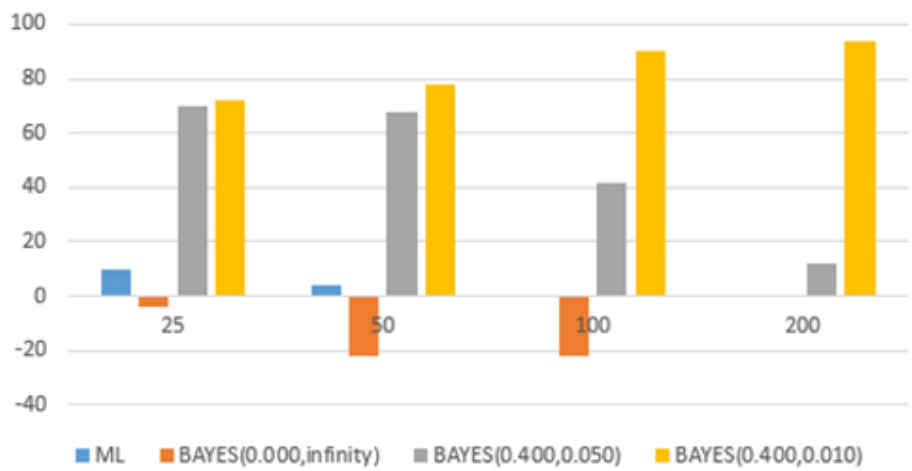

Faktör Yükü:0.4, r=0.5

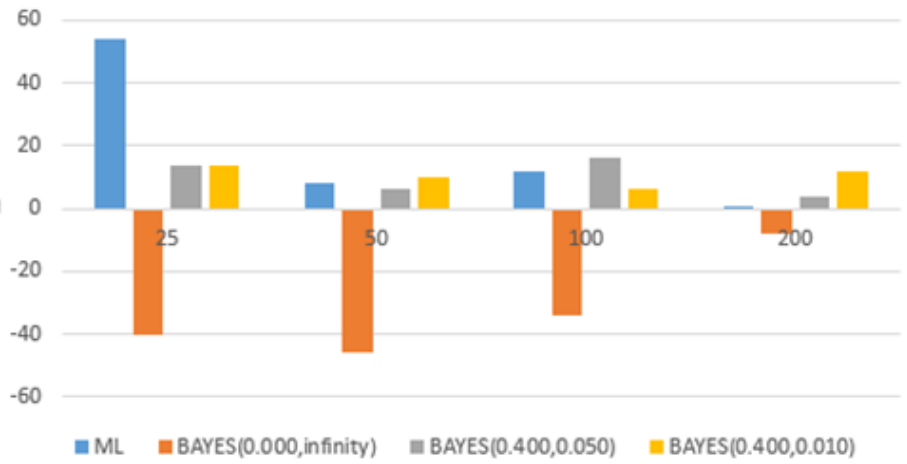

Şekil 4. Faktörler arası korelasyon güçlü olduğu durumda her bir örneklem büyüiklü̆̆̈̈i için faktörler arası korelasyonun parametre kestirim yanlılı̆̆ 
Faktör yüklerinin 0,80 olduğu durumlarda, faktörler arası korelasyonun zayıf olduğu durumda: 25 kişilik örneklemde faktörler arası korelasyon parametre kestirim yanlılığ $\infty)$ Bayes, maksimum olabilirlik, bilgilendirici $\mathrm{N}(0.40,0.05)$ Bayes, bilgilendirici $\mathrm{N}(0.40,0.01)$ Bayes şeklindedir. Gerçek değere en yakın sonuçları bilgilendirici olmayan Bayes kestirimi vermiştir. Maksimum olabilirlik ile yapılan kestirimler gerçek değerinden düşük, diğer yöntemlerle yapılan kestirimler gerçek değerinden yüksek kestirilmiştir. Diğer örneklem büyüklüklerinde; yapılan kestirimler gerçek değerinden düşük kestirilmiştir, bilgilendirici olmayan $\mathrm{N}(0, \infty)$ Bayes ve maksimum olabilirlik birbirine çok yakın ve neredeyse yansız faktörler arası korelasyon parametre kestirimi vermektedir. 200 kişilik örneklemde dört farklı kestirim ile de faktörler arası korelasyon neredeyse yansız kestirilmiştir. 100 kişi ve altındaki örneklemlerde bilgilendirici $\mathrm{N}(0.40,0.05)$ Bayes kestirimi, bilgilendirici $\mathrm{N}(0.40,0.01)$ Bayes kestiriminden daha az yanlı kestirilmler yapmıştır.

Faktör yüklerinin 0,80 olduğu durumlarda, faktörler arası korelasyonun güçlü olduğu durumda: tüm örneklem büyüklüklerinde bilgilendirici olmayan $\mathrm{N}(0, \infty)$ Bayes ve maksimum olabilirlik birbirine çok yakın ve 25 kişide neredeyse yansız, 50 ve üzerinde yansız sonuçlar vermektedir. Bilgilendirici $\mathrm{N}(0.40,0.05)$ Bayes, bilgilendirici $\mathrm{N}(0.40,0.01)$ Bayesten daha az yanlı sonuçlar vermektedir. Tüm yöntemlerle yapılan faktörler arası korelasyon parametre kestirimleri gerçek değerinden yüksek kestirilmiştir.

Faktör yüklerinin 0,60 olduğu durumlarda, faktörler arası korelasyonun zayıf olduğu durumda: 25 kişilik örneklemde, faktörler arası korelasyon parametre kestirim yanlılı̆̆ en küçükten en büyüğe maksimum olabilirlik, bilgilendirici olmayan $\mathrm{N}(0, \infty)$ Bayes, bilgilendirici $\mathrm{N}(0.40,0.01)$ Bayes, bilgilendirici $\mathrm{N}(0.40,0.05)$ Bayes şeklindedir. 50 ve üzerindeki örneklemlerde maksimum olabilirlik ve bilgilendirici olmayan $\mathrm{N}(0, \infty)$ Bayes neredeyse yansız sonuçlar vermiştir. 50 ve 100 kişide bilgilendirici N(0.40, 0.01) Bayes kestirimi, bilgilendirici $\mathrm{N}(0.40,0.05)$ kestiriminden daha yanlı sonuçlar vermiştir. 200 kişilik örneklemde bilgilendirici $\mathrm{N}(0.40,0.05)$ kestirimi çok düşük düzeyde yanlı sonuçlar verirken, bilgilendirici $\mathrm{N}(0.40,0.01)$ Bayes kestirimi oldukça yanlı sonuçlar vermiştir.

Faktör yüklerinin 0,60 olduğu durumlarda, faktörler arası korelasyonun güçlü olduğu durumda: 25 kişilik örneklemde, faktörler arası korelasyon parametre kestirim yanlılığı en küçükten en büyüğe bilgilendirici olmayan $\mathrm{N}(0$, 
$\infty)$ Bayes, maksimum olabilirlik, bilgilendirici $\mathrm{N}(0.40,0.05)$ Bayes, bilgilendirici N $(0.40,0.01)$ Bayes şeklindedir. Gerçek değere en yakın sonuçları bilgilendirici olmayan Bayes kestirimi vermiştir. 50 ve 100 kişilik örneklemde kestirim yanlılığı en küçükten en büyüğe maksimum olabilirlik, bilgilendirici olmayan $\mathrm{N}(0, \infty)$ Bayes, bilgilendirici $\mathrm{N}(0.40,0.05)$ Bayes, bilgilendirici $\mathrm{N}(0.40$, 0.01) Bayes şeklindedir. 100 kişilik örneklemde maksimum olabilirlik, $200 \mathrm{ki}-$ şilik örneklemde maksimum olabilirlik ve bilgilendirici olmayan $\mathrm{N}(0, \infty)$ Bayes yansız sonuçlar vermiştir. Bilgilendirici olmayan Bayes ile yapılan kestirim gerçek değerinden düşük, diğer yöntemlerle yapılan kestirimler gerçek değerinden yüksek kestirilmiştir.

Faktör yüklerinin 0.40 olduğu durumlarda: Bilgilendirici olmayan $\mathrm{N}(0, \infty)$ Bayes yöntemiyle yapılan kestirimler gerçek değerinden düşük, diğer yöntemlerle yapılan kestirim gerçek değerinden yüksek kestirilmiştir. 25 kişilik örneklemde; düşük korelasyon koşulunda faktörler arası korelasyon parametre kestirim yanlılığı en küçükten en büyüğe bilgilendirici $\mathrm{N}(0.40,0.05) \mathrm{Ba}-$ yes, bilgilendirici $\mathrm{N}(0.40,0.01)$ Bayes, bilgilendirici olmayan $\mathrm{N}(0, \infty)$ Bayes, maksimum olabilirlik şeklindedir. Gerçek değere en yakın sonuçları bilgilendirici $\mathrm{N}(0.40,0.05)$ Bayes vermiştir. Yüksek korelasyon koşulunda ise bilgilendirici $\mathrm{N}(0.40,0.05)$ Bayes, bilgilendirici $\mathrm{N}(0.40,0.01)$ Bayes neredeyse ayn1 kestirim yanlılığı sonuçlarla gerçek değere en yakın kestirimleri yapmış, bunu sirasıyla bilgilendirici olmayan $\mathrm{N}(0, \infty)$ Bayes, maksimum olabilirlik takip etmiştir. 50 kişilik örneklemde; düşük korelasyon koşulunda faktörler arası korelasyon parametre kestirim yanlılığı en küçük yöntem bilgilendirici $\mathrm{N}(0.40,0.05)$ Bayes, en büyük yöntem bilgilendirici olmayan $\mathrm{N}(0, \infty)$ Bayestir, maksimum olabilirlik ile bilgilendirici $\mathrm{N}(0.40,0.01)$ Bayes aynı sonuçları vermiştir. Yüksek korelasyon koşulunda faktörler arası korelasyon parametre kestirim yanlılığ en küçükten en büyüğe bilgilendirici $N(0.40,0.05)$ Bayes, maksimum olabilirlik, bilgilendirici $\mathrm{N}(0.40,0.01)$ Bayes, bilgilendirici olmayan $\mathrm{N}(0, \infty)$ Bayes şeklindedir. Gerçek değere en yakın sonuçları bilgilendirici $\mathrm{N}(0.40,0.05)$ Bayes vermiştir. 100 kişilik örneklemde; düşük korelasyon koşulunda bilgilendirici olmayan $\mathrm{N}(0, \infty)$ Bayes ve maksimum olabilirlik birbirine çok yakın ve en küçük kestirim yanlılı̆̆ı değerini vermiş̧tir, bunu sırasiyla bilgilendirici $\mathrm{N}(0.40,0.05)$ Bayes, bilgilendirici $\mathrm{N}(0.40,0.01)$ Bayes takip etmiştir. Yüksek korelasyon koşulunda kestirim yanlılığı en küçükten en büyüğe bilgilendirici $\mathrm{N}(0.40,0.01)$ Bayes, maksimum olabilirlik, bilgilendirici $\mathrm{N}(0.40,0.05)$ Bayes, bilgilendirici olmayan $\mathrm{N}(0, \infty)$ Bayes şeklindedir. Gerçek 
değere en yakın sonuçları bilgilendirici $\mathrm{N}(0.40,0.01)$ Bayes vermiştir. Örneklem büyüklügünün 200 olduğu koşul için hem düşük hem de yüksek korelasyon koşulunda kestirim yanlılığı en küçükten en büyüğe maksimum olabilirlik, bilgilendirici $N(0.40,0.05)$ Bayes, bilgilendirici olmayan $N(0, \infty)$ Bayes, bilgilendirici $\mathrm{N}(0.40,0.01)$ Bayes şeklindedir. Gerçek değere en yakın sonuçları maksimum olabilirlik kestirimi vermiştir.

\section{Hata Kareler Ortalamasına İlişkin Bulgular}

Faktör Yüklerinin Hata Kareler Ortalamasına İlişkin Bulgular: Her bir örneklem büyüklüğ̈̈ ( $\mathrm{N}=25, \mathrm{~N}=50, \mathrm{~N}=100, \mathrm{~N}=200)$ için, faktörler arası korelasyon zayıf ( $\mathrm{r}=0.30$ ) olduğu durumdaki faktör yüklerinin hata kareler ortalamasına ilişkin bulgular Şekil 5'te, faktörler arası korelasyon güçlü (r=0.50) olduğu durumdaki faktör yüklerinin hata kareler ortalamasına ilişkin bulgular Şekil 6'da verilmiştir.

Şekil 5 ve Şekil 6 birlikte incelendiğinde, faktör yüklerinin hata kareler ortalaması faktörler arası korelasyona göre farklılaşmamaktadır.

Faktör yükünün 0,80 olduğu koşulda, hem zayıf hem de güçlü faktörler arası korelasyonda, 25 ve 50 kişilik örneklem büyüklüklerinde, maksimum olabilirlik ile bilgilendirici olmayan $\mathrm{N}(0, \infty)$ Bayes çok yakın olmakla birlikte, hata kareler ortalaması en küçükten en büyüğe sırasıyla maksimum olabilirlik, bilgilendirici olmayan $\mathrm{N}(0, \infty)$ Bayes, bilgilendirici $\mathrm{N}(0.40,0.05)$ Bayes, bilgilendirici $\mathrm{N}(0.40,0.01)$ Bayes şeklindedir. 100 ve 200 kişilik örneklemlerde maksimum olabilirlik, bilgilendirici olmayan $\mathrm{N}(0, \infty)$ Bayes ve bilgilendirici $\mathrm{N}(0.40,0.05)$ Bayes yaklaşık eşit ve bilgilendirici $\mathrm{N}(0.40,0.01)$ Bayes kestiriminden düşük değerler vermiştir.

Faktör yükünün 0,60 olduğu koşulda, 25 kişilik örneklemde bilgilendirici $\mathrm{N}(0.40,0.05)$ Bayes ve bilgilendirici $\mathrm{N}(0.40,0.01)$ Bayes çok yakın olmakla birlikte, hata kareler ortalaması en küçükten en büyüğe sırasıyla bilgilendirici $\mathrm{N}(0.40,0.01)$ Bayes, bilgilendirici $\mathrm{N}(0.40,0.05)$ Bayes, bilgilendirici olmayan $\mathrm{N}(0, \infty)$ Bayes, maksimum olabilirlik şeklindedir. 50 kişilik örneklemde Bayes kestirimleri birbirine yakın ve maksimum olabilirlikten daha düşüktür. 100 ve 200 kişilik örneklemde ise bilgilendirici $N(0.40,0.01)$ Bayes daha yüksek değerler verirken diğer üç teknik ile birbirine yakın hata kareler ortalaması elde edilmiştir. 
Faktör yükü:0.8, $\mathrm{r}=0.3$

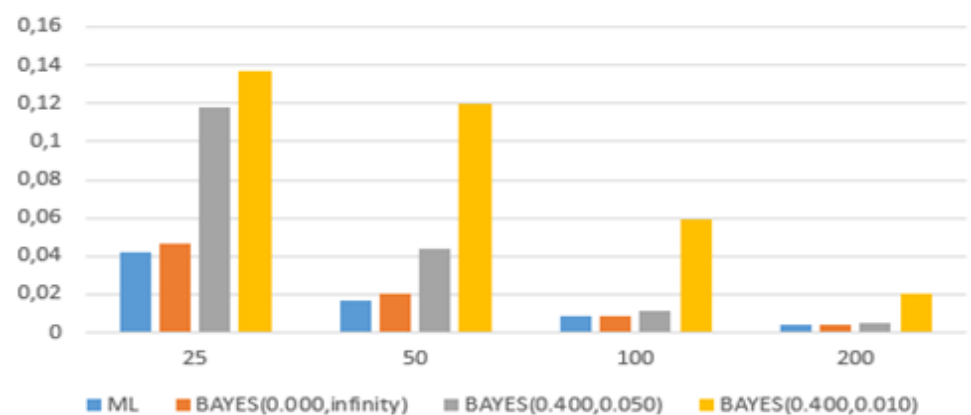

Faktör Yükü:0.6, r=0.3

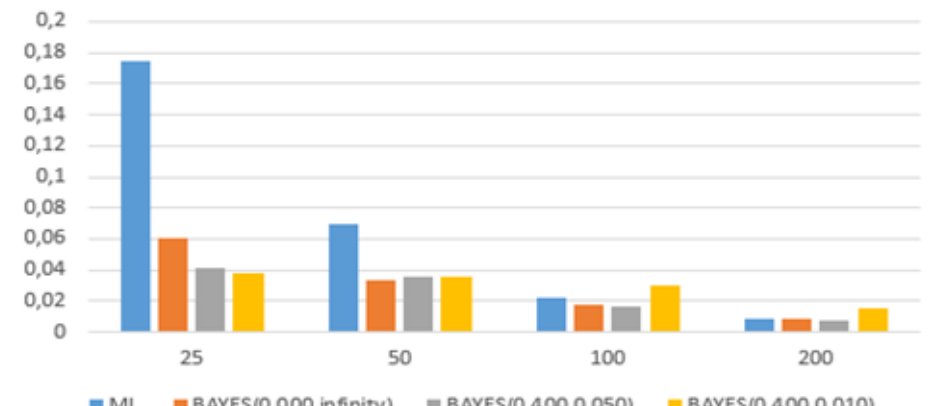

Faktör Yükü:0.4, r=0.3

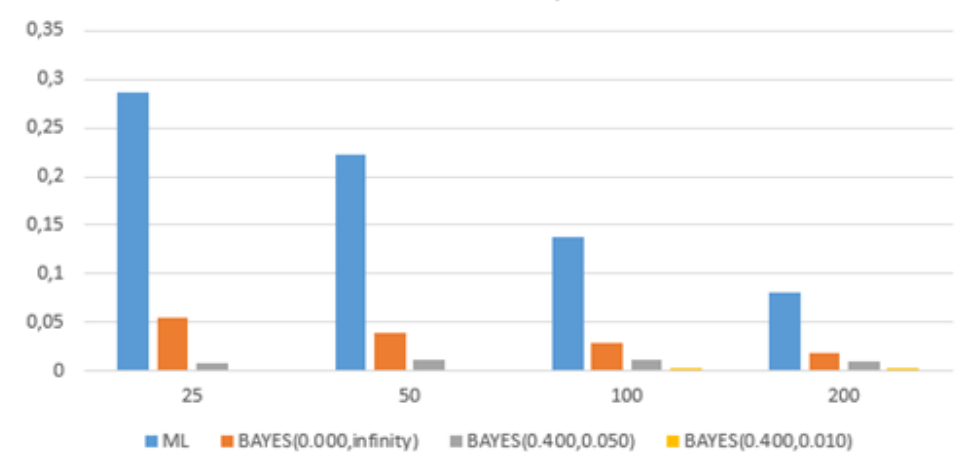

Şekil 5. Faktörler arası korelasyon zayıf olduğu durumda her bir örneklem büyüklü̈̆̈̈ için faktör yüklerinin hata kareler ortalaması 


\section{Faktör Yükü:0.8, r=0.5}

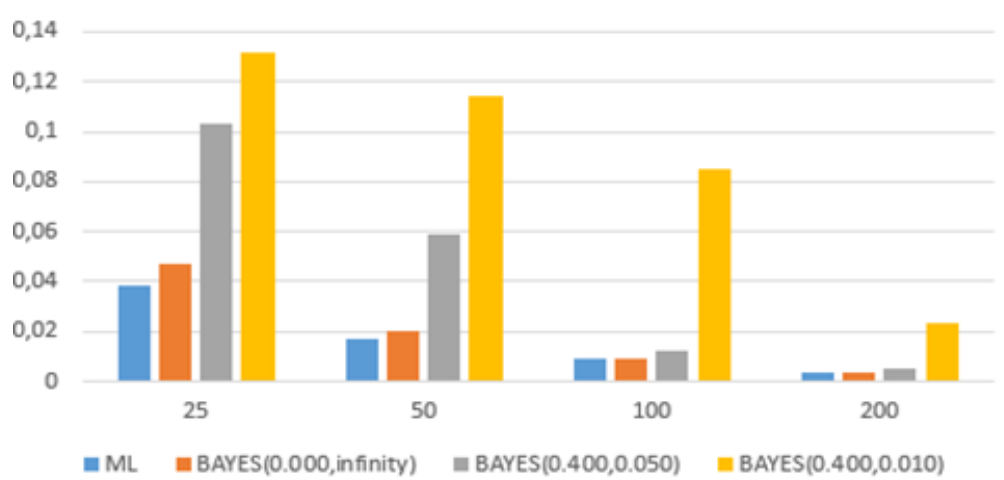

Faktör Yükü:0.6, r=0.5

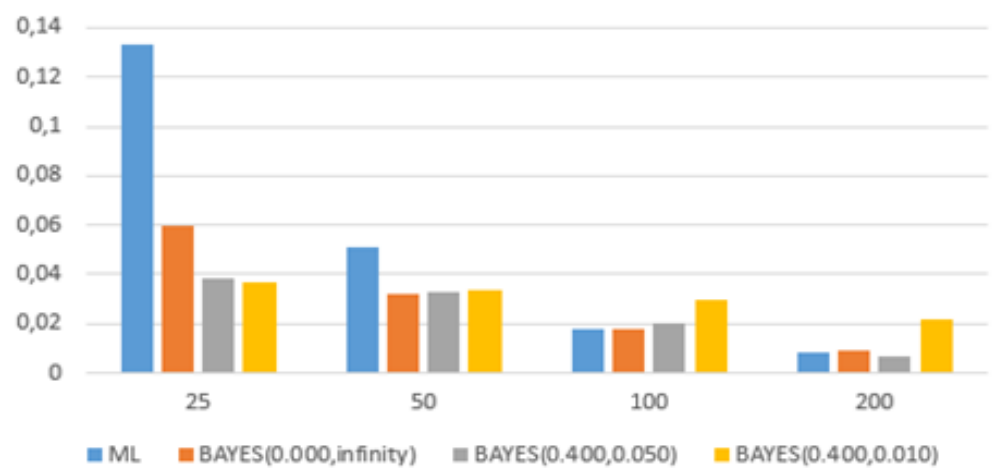

Faktör Yükü:0.4, r=0.5

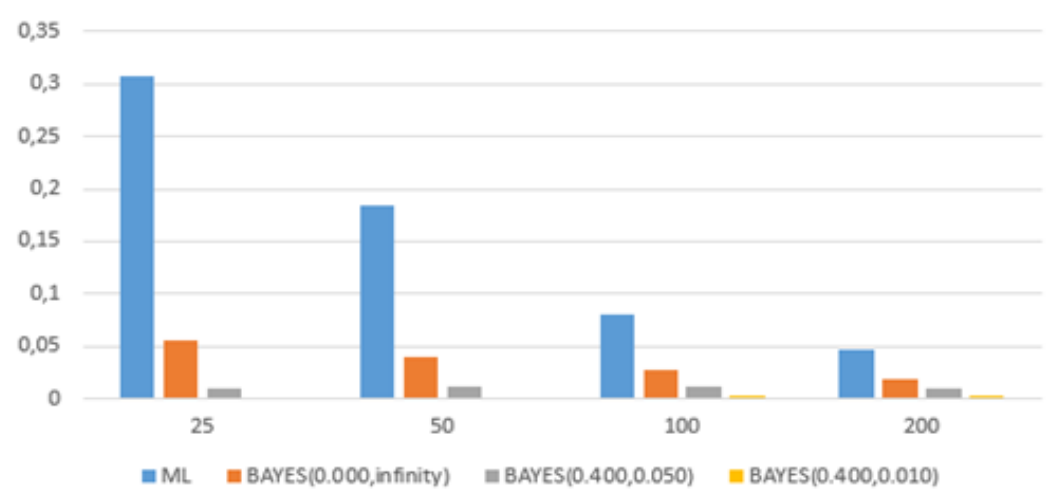

Şekil 6. Faktörler arası korelasyon güçlü olduğu durumda her bir örneklem büyüklï̈̆̈̈ için faktör yüklerinin hata kareler ortalaması. 
Faktör yükünün 0,40 olduğu koşulda, tüm örneklem büyüklüklerinde ve zayıf ve güçlü faktörler arası korelasyon durumlarında hata kareler ortalaması en küçükten en büyüğe sırasıyla bilgilendirici $\mathrm{N}(0.40,0.01)$ Bayes, bilgilendirici $\mathrm{N}(0.40,0.05)$ Bayes, bilgilendirici olmayan $\mathrm{N}(0, \infty)$ Bayes, maksimum olabilirlik şeklindedir.

Faktörler Arası Korelasyonun Hata Kareler Ortalamasına İlişkin Bulgular

Her bir örneklem büyüklüğ̈̈ ( $N=25, N=50, N=100, N=200$ ) için, faktörler arası korelasyon zayıf $(\mathrm{r}=0.30)$ olduğu durumdaki faktörler arası korelasyonun hata kareler ortalamasına ilişkin bulgular Şekil 7'de, faktörler arası korelasyon güçlü $(r=0.50)$ olduğu durumdaki faktörler arası korelasyonun hata kareler ortalamasına ilişkin bulgular Şekil 8' de verilmiştir.

Şekil 7 ve Şekil 8 birlikte incelendiğinde; faktör yükünün 0,80 olduğu koşulda, 25 kişilik örneklemde hem zayıf hem de güçlü faktörler arası korelasyon koşullarında bilgilendirici olmayan $\mathrm{N}(0, \infty)$ Bayes ile maksimum olabilirlik birbirine yakın düşük, bilgilendirici $\mathrm{N}(0.40,0.05)$ ve $\mathrm{N}(0.40,0.01)$ Bayes birbirine yakın yüksek faktörler arası korelasyonun hata kareler ortalaması değeri vermiştir. 50 kişilik örneklemde hem zayıf hem de güçlü faktörler arası korelasyon koşullarında bilgilendirici olmayan $\mathrm{N}(0, \infty)$ Bayes ile maksimum olabilirlik birbirine yakın düşük değerler vermiş, bunu sırasıyla bilgilendirici $\mathrm{N}(0.40,0.05)$ Bayes ve bilgilendirici $\mathrm{N}(0.40,0.01)$ Bayes takip etmiştir. $100 \mathrm{ki}-$ şilik örneklemde bilgilendirici $\mathrm{N}(0.40,0.01)$ Bayes hariç üç yöntem, 200 kişilik örneklemde tüm yöntemler sıfıra çok yakın faktörler arası korelasyonun hata kareler ortalaması değeri vermiştir. 
Faktör yükü:0.8, r=0.3

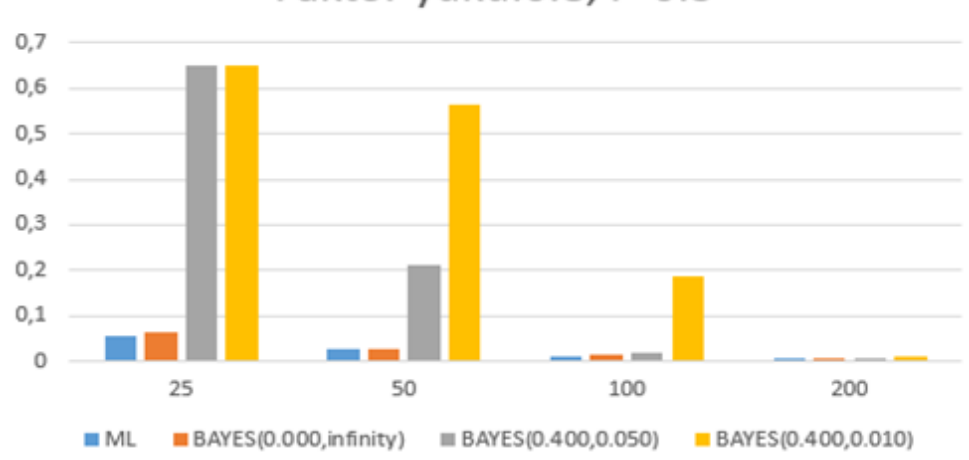

Faktör yükü:0.6, $r=0.3$

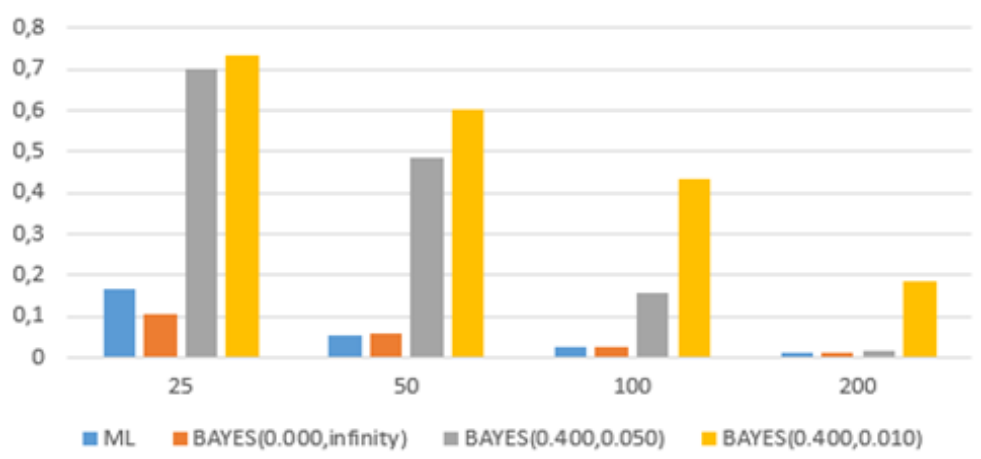

Faktör yükü:0.4, r=0.3

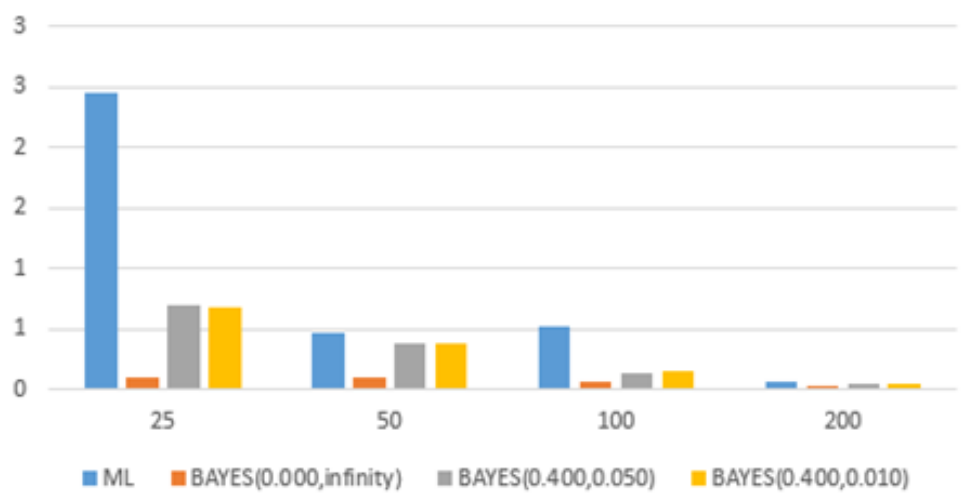

Şekil 7. Faktörler arası korelasyon zayıf olduğu durumda her bir örneklem büiyüklüğ̈̈ için faktörler arası korelasyonun hata kareler ortalaması 
Faktör Yükü: $0.8, \mathrm{r}=0.5$

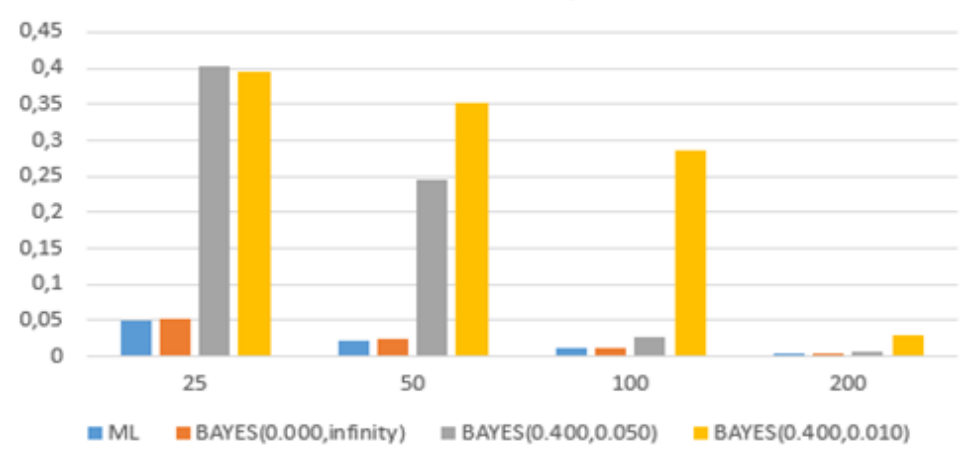

Faktör yükü:0.6, r=0.5

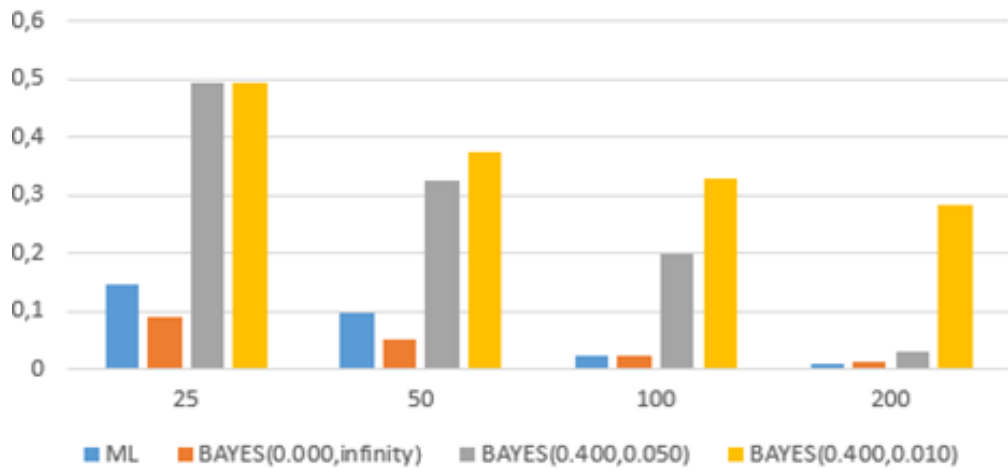

Faktör yükü:0.4, $r=0.5$

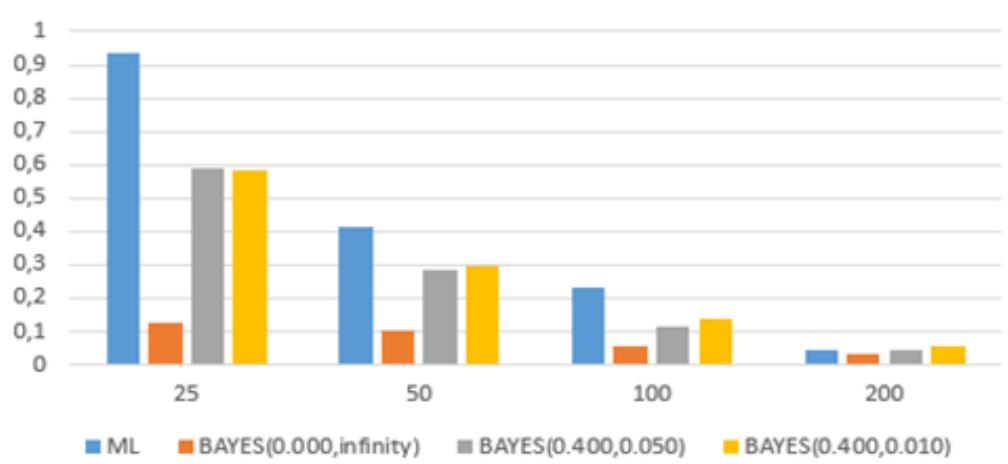

Şekil 8. Faktörler arası korelasyon güçlü olduğu durumda her bir örneklem büyü̈klü̆̆̈̈i için faktörler arası korelasyonun hata kareler ortalaması 
Faktör yükünün 0,40 olduğu koşulda, 25 kişilik örneklemde hem zayıf hem de güçlü faktörler arası korelasyon koşullarında bilgilendirici $\mathrm{N}(0.40$, 0.05) Bayes ile bilgilendirici $\mathrm{N}(0.40,0.01)$ Bayes birbirine çok yakın olmakla birlikte hata kareler ortalaması en küçükten en büyüğe sırasıyla bilgilendirici olmayan $\mathrm{N}(0, \infty)$ Bayes, bilgilendirici $\mathrm{N}(0.40,0.05)$ Bayes, bilgilendirici $\mathrm{N}(0.40$, 0.01) Bayes ve maksimum olabilirlik şeklindedir. 50 kişilik örneklemde hem zayıf hem de güçlü faktörler arası korelasyon koşullarında bilgilendirici $\mathrm{N}(0.40,0.05)$ Bayes ile bilgilendirici $\mathrm{N}(0.40,0.01)$ Bayes birbirine çok yakın olmakla birlikte hata kareler ortalaması en küçükten en büyüğe sırasıyla bilgilendirici olmayan $\mathrm{N}(0, \infty)$ Bayes, bilgilendirici $\mathrm{N}(0.40,0.05)$ Bayes, bilgilendirici $\mathrm{N}(0.40,0.01)$ Bayes ve maksimum olabilirlik şeklindedir. 100 kişilik örneklemde hem zayıf hem de güçlü faktörler arası korelasyon koşullarında bilgilendirici $\mathrm{N}(0.40,0.05)$ Bayes ile bilgilendirici $\mathrm{N}(0.40,0.01)$ Bayes birbirine çok yakın olmakla birlikte hata kareler ortalaması en küu̧ükten en büyüğe s1rasiyla bilgilendirici olmayan $\mathrm{N}(0, \infty)$ Bayes, bilgilendirici $\mathrm{N}(0.40,0.05)$ Bayes, bilgilendirici $\mathrm{N}(0.40,0.01)$ Bayes ve maksimum olabilirlik şeklindedir. $200 \mathrm{ki}-$ şilik örneklemde hem zayıf hem de güçlü faktörler arası korelasyon koşullarinda maksimum olabilirlik, bilgilendirici olmayan $\mathrm{N}(0, \infty)$ Bayes, bilgilendirici $\mathrm{N}(0.40,0.05)$ Bayes ve bilgilendirici $\mathrm{N}(0.40,0.01)$ Bayes birbirine çok yakın faktörler arası korelasyonun hata kareler ortalaması değeri vermiştir.

İstatistiksel Güce (Faktörler Arası Korelasyon) İlişkin Bulgular

Her bir örneklem büyüklüğü (N=25, N=50, N=100, N=200) için faktörler arası korelasyon zayıf ( $\mathrm{r}=0.30)$ olduğu durumda istatistiksel güce ilişkin bulgular Şekil 9'da, faktörler arası korelasyon güçlü $(r=0.50)$ olduğu durumda istatistiksel güce ilişkin bulgular Şekil 10' da verilmiştir.

Şekil 9 ve Şekil 10 birlikte incelendiğinde, faktör yükünün yüksek $(0,80)$ olduğu koşulda, 25 kişilik örneklemde hem zayıf hem de güçlü faktörler arası korelasyon koşullarında hata kareler ortalaması en küçükten en büyüğe sırasıyla bilgilendirici olmayan $\mathrm{N}(0, \infty)$ Bayes, maksimum olabilirlik, bilgilendirici $\mathrm{N}(0.40,0.05)$ Bayes ve bilgilendirici $\mathrm{N}(0.40,0.01)$ Bayes şeklindedir. 50 kişilik örneklemde hem zayıf hem de güçlü faktörler arası korelasyon koşullarında maksimum olabilirlik ile bilgilendirici $\mathrm{N}(0.40,0.05)$ Bayes birbirine çok yakın olmakla birlikte hata kareler ortalaması en küçükten en büyüğe bilgilendirici olmayan $\mathrm{N}(0, \infty)$ Bayes, maksimum olabilirlik, bilgilendirici $\mathrm{N}(0.40$, 0.05) Bayes ve bilgilendirici $N(0.40,0.01)$ Bayes şeklindedir. 100 kişilik örneklemde örneklemde zayıf faktörler arası korelasyon koşullarında maksimum 
olabilirlik ile bilgilendirici $\mathrm{N}(0.40,0.05)$ Bayes birbirine çok yakın olmakla birlikte hata kareler ortalaması en küçükten en büyüğe bilgilendirici olmayan $\mathrm{N}(0, \infty)$ Bayes, bilgilendirici $\mathrm{N}(0.40,0.05)$ Bayes, maksimum olabilirlik ve bilgilendirici $\mathrm{N}(0.40,0.01)$ Bayes şeklinde güçlü faktörler arası korelasyon koşullarında maksimum olabilirlik, bilgilendirici olmayan $\mathrm{N}(0, \infty)$ Bayes, bilgilendirici $\mathrm{N}(0.40,0.05)$ Bayes ve bilgilendirici $\mathrm{N}(0.40,0.01)$ Bayes birbirine çok yakın faktörler arası korelasyonun hata kareler ortalaması değeri vermiştir. 200 kişilik örneklemde hem zayıf hem de güçlü faktörler arası korelasyon koşullarında maksimum olabilirlik, bilgilendirici olmayan $\mathrm{N}(0, \infty)$ Bayes, bilgilendirici $\mathrm{N}(0.40,0.05)$ Bayes ve bilgilendirici $\mathrm{N}(0.40,0.01)$ Bayes birbirine çok yakın faktörler arası korelasyonun hata kareler ortalaması değeri vermiştir. 200 kişilik örneklemde güçlü faktörler arası korelasyon koşullarındaki hata kareler ortalamaları değerlerinin 100 kişilik örneklemde güçlü faktörler arası korelasyon koşullarındaki hata kareler ortalamaları değerleri ile hemen hemen aynı olduğu görülmektedir.

\section{Faktör Yükü:0.8, r=0.3}

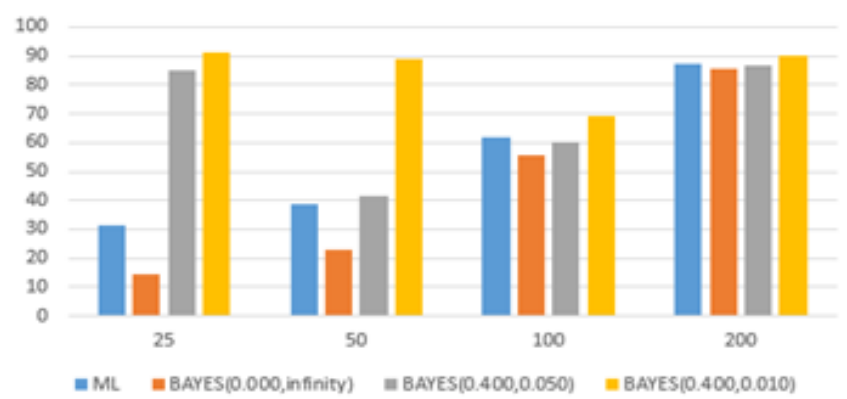

Faktör Yükü:0.4, r=0.3

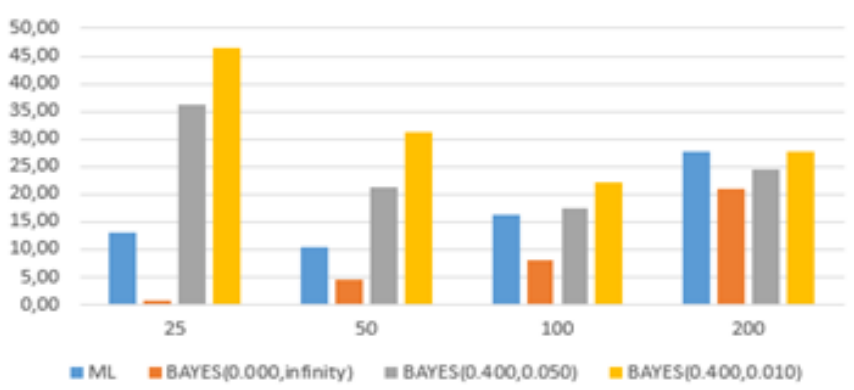

Şekil 9. Faktörler arası korelasyon zayıf olduğu durumda her bir örneklem büyükklüğ̈̈ için istatistiksel güç 


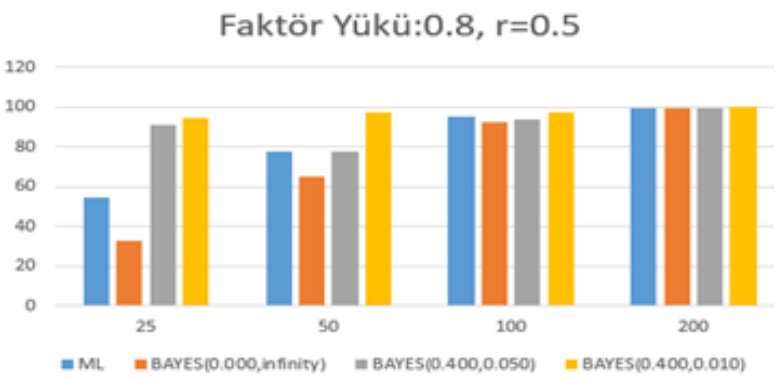

Faktör Yükü:0.4, r=0.5

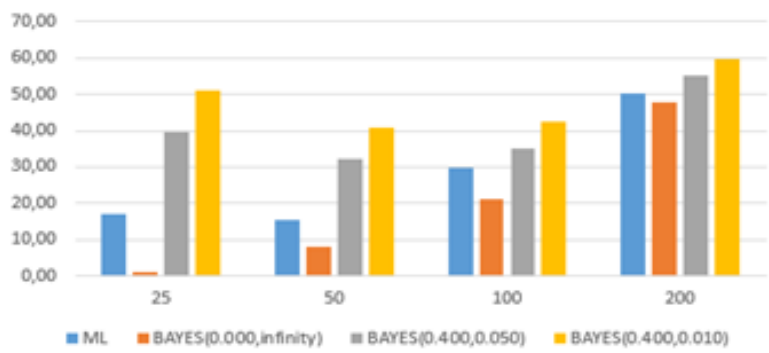

Şekil 10. Faktörler arası korelasyon güçlü olduğu durumda her bir örneklem büyüklüğ̈̈ için istatistiksel güç

Faktör yükünün düşük $(0,40)$ olduğu koşulda, 25 kişilik örneklemde hem zayıf hem de güçlü faktörler arası korelasyon koşullarında hata kareler ortalaması en küçükten en büyüğe sırasıyla bilgilendirici olmayan $\mathrm{N}(0, \infty)$ Bayes, maksimum olabilirlik, bilgilendirici $\mathrm{N}(0.40,0.05)$ Bayes ve bilgilendirici $\mathrm{N}(0.40,0.01)$ Bayes şeklindedir. 50 kişilik örneklemde hem zayıf hem de güçlü faktörler arası korelasyon koşullarında hata kareler ortalaması en küçükten en büyüğe sırasıyla bilgilendirici olmayan $\mathrm{N}(0, \infty)$ Bayes, maksimum olabilirlik, bilgilendirici $\mathrm{N}(0.40,0.05)$ Bayes ve bilgilendirici $\mathrm{N}(0.40,0.01)$ Bayes şeklindedir. 100 kişilik örneklemde hem zayıf hem de güçlü faktörler arası korelasyon koşullarında hata kareler ortalaması en küçükten en büyüğe sırasıyla bilgilendirici olmayan $\mathrm{N}(0, \infty)$ Bayes, maksimum olabilirlik, bilgilendirici $\mathrm{N}(0.40,0.05)$ Bayes ve bilgilendirici N(0.40, 0.01) Bayes şeklindedir. 200 kişilik örneklemde zayıf faktörler arası korelasyon koşullarında maksimum olabilirlik ile bilgilendirici N(0.40, 0.01) Bayes birbirine çok yakın olmakla birlikte hata kareler ortalaması en küçükten en büyüğe bilgilendirici olmayan $N(0, \infty)$ Bayes, bilgilendirici $\mathrm{N}(0.40,0.05)$ Bayes, bilgilendirici $\mathrm{N}(0.40,0.01)$ Bayes ve 
maksimum olabilirlik şeklinde, güçlü faktörler arası korelasyon koşullarında maksimum olabilirlik ile bilgilendirici olmayan $\mathrm{N}(0, \infty)$ Bayes birbirine çok yakın olmakla birlikte hata kareler ortalaması en küçükten en büyüğe maksimum olabilirlik, bilgilendirici olmayan $\mathrm{N}(0, \infty)$ Bayes, bilgilendirici $\mathrm{N}(0.40$, $0.05)$ Bayes ve bilgilendirici $\mathrm{N}(0.40,0.01)$ Bayes şeklindedir.

\section{Sonuç, Tartışma ve Öneriler}

Maksimum olabilirlik kestirimine dayalı DFA'da: Örneklem büyüklügü arttıkça ve faktör yükleri yükseldikçe faktör yüklerinin parametre kestirim yanlılığ 1 ve hata kareler ortalaması azalmaktadır. Faktör yüklerinin yüksek olduğu durumda, faktörler arası korelasyonun güçlü ya da zayıf olması faktör yüklerinin parametre kestirim yanlılığını (negatif değerler almıştır yani olduğu değerden daha düşük kestirilmiştir) ve hata kareler ortalamasını etkilememektedir. Faktör yükleri düştükçe; faktörler arası korelasyonun düşük olduğu durumda faktör yüklerinin parametre kestirim yanlılığ (pozitif değerler almıştır yani olduğu değerden daha yüksek kestirilmiştir) artmaktadır. Orta ve düşük faktör yüklerinde, faktörler arası korelasyon güçlü olduğunda faktör yüklerinin hata kareler ortalaması daha düşüktür. Örneklem büyüklüğü, faktör yükleri ve faktörler arası korelasyon yüksek olduğunda istatistiksel güç yüksektir. Heerwegh (2014) yaptığı çalışmada benzer bulgulara ulaşmış ve maksimum olabilirlik kestiriminin büyük örneklem teorisine dayandığından, küçük örneklemlerde problemli sonuçlara yol açtığını raporlamıştır. Örneklem büyüklüğünün ve faktör yükünün azaldığı durumda yap1lan kestirimlerin hata kareler ortalaması artmaktadır. Wolf ve arkadaşlarının (2013) çalışmasında da faktör yükleri ve faktörler arası korelasyon yükseldiğinde gereken minimum örneklem büyüklüğünün azaldığı belirtilmiştir.

Maksimum olabilirlik kestirimine dayalı DFA'da: 50 ve üzerindeki örneklem büyüklüklerinde, faktör yüklerinin yüksek olması durumunda, faktörler arası korelasyonun parametre kestirimleri; faktörler arası korelasyon zayıf olduğunda çok düşük düzeyde yanlı, faktörler arası korelasyon güçlü olduğunda yansızdır. 100 ve üzerindeki örneklem büyüklüklerinde, faktör yüklerinin orta olması durumunda, faktörler arası korelasyonun parametre kestirimleri; faktörler arası korelasyon zayıf olduğunda çok düşük düzeyde yanlı, faktörler arası korelasyon güçlü olduğunda yansızdır. Faktör yüklerinin dü- 
şük olduğu durumlarda; özellikle küçük örneklemlerde faktörler arası korelasyonun parametre kestirim yanlılı̆̆ yüksektir. Faktörler arası korelasyonun azalması faktörler arası korelasyonun parametre kestirim yanlılı̆ıın arttırmaktadır. 200 kişilik örneklemde, faktör yükleri düşük olsa bile hem zayıf hem de güçlü faktörler arası korelasyon koşullarında faktörler arası korelasyonun parametre kestirimleri düşük düzeyde yanlıdır. Heerwegh (2014) yaptığı çalışmada, maksimum olabilirlik kestiriminin parametre kestirim yanlılığının, faktörler arası korelasyon güçlü olduğunda daha düşük (gerçek değerine yakın) olduğunu ve zayıf faktör yükü durumunda özellikle çok küçük örneklemlerde yapılan kestirimlerin faktörler arası korelasyon parametre kestirim yanlılığının artış gösterdiğini raporlamıştır.

Bayes yaklaşımına dayalı DFA'da: Bilgilendirici önseller yanlılı̆̆ı azaltıp istatistiksel gücü arttırmaktadır. Gerçek faktör yüklerinin olduğundan daha düşük kestirildiği bilgilendirici önseller diğer model parametrelerinde yüksek yanlılık verebilir. Bayes yaklaşımına dayalı DFA avantajlı olmasına rağmen model için hangi önselin seçileceğine dikkatli karar verilmelidir (Heerwegh, 2014). Bu çalışmada bu bilgilerle paralel sonuçlara ulaşılmıştır. Bilgilendirici önseller yanlış tanımlandığında (yani gerçek faktör yükleri ortalaması 0,60 ya da 0,80 iken önselin faktör yük ortalaması 0,40 'a sabitlendiğinde), faktör yüklerinin parametre kestirim yanlıllğı artmaktadır. Bilgilendirici önsellerin faktör ortalaması gerçek değere ne kadar yakınsa faktör yüklerinin parametre kestirim yanlılığı o kadar düşmektedir. Bilgilendirici önsel kullanılan Bayes yaklaşımına dayalı DFA koşullarının tümünde kestirimler olduğundan daha düşüktür yani faktör yüklerinin parametre kestirim yanl1lığ 1 değerleri negatiftir. Önsel daha fazla bilgilendiriciyse yani varyans değeri daha düşükse, yanlış tanımlanmış koşullarda faktör yüklerinin parametre kestirim yanlılığı daha yüksektir. Tanımlamanın doğru yapıldığı durumda, varyans değeri daha düşük olan yani daha bilgilendirici olan önsel önselin faktör yüklerinin parametre kestirim yanlılığı daha düşüktür. Bilgilendirici önseller için faktör yüklerinin parametre kestirim yanlılı̆̆ faktörler arası korelasyonun zayıf ya da güçlü olma durumuna göre farklılaşmamaktadır. Orta ve yüksek faktör yüklerinde, önseller hatalı tanımlandığında, faktörler arası korelasyonlar \%170'lere kadar yüksek tahmin edilmiştir. Heerwegh (2014) çalışmasında bu değerlerin \%200'lere ulaştığını raporlamıştır. 
Bayes yaklaşımına dayalı DFA'da: bilgilendirici olmayan önsel orta ve yüksek faktör yüklerinde faktör yüklerinin parametre kestirim yanlılığı pozitiftir (olduğundan daha yüksek kestirilmiştir). Düşük faktör yüklerinde ise faktör yüklerinin parametre kestirim yanlılı̆̆ 1 değeri negatiftir, kestirimler olduğundan daha düşüktür. Bilgilendirici olmayan önsel için faktör yüklerinin parametre kestirim yanlılığı faktörler arası korelasyonun zayıf ya da güçlü olma durumuna göre farklılaşmamaktadır.

Bilgilendirici önseller ile bilgilendirici olmayan önseller birlikte incelendiğinde: Örneklem büyüklüğü arttıkça hem bilgilendirici hem de bilgilendirici olmayan önselli Bayes yaklaşımına dayalı DFA'da faktör yüklerinin parametre kestirim yanlılığı azalmaktadır. Faktör yükünün düşük olduğu durumda: 25 kişilik örneklemde bilgilendirici önseller ile yapılan kestirim bilgilendirici olmayan önsel ile yapılan kestirimlerden daha yansız sonuçlar vermiştir. Düşük faktör yükünde, hem güçlü hem de zayıf faktörler arası korelasyon durumunda, bilgilendirici olmayan önseller faktör korelasyonunun gerçek değerinden daha düşük kestirilmesine neden olurken bilgilendirici önseller gerçek değerinden daha yüksek kestirim yapmıştır. Önseller doğru belirlendiğinde bile, bilgilendirici olmayan önseller ile yapılan faktörler arası korelasyon kestiriminin hata kareler ortalaması değeri bilgilendirici önsellerin kullanıldığı durumdan düşük çıkmıştır. Bu bulgu, farklı faktörler arası korelasyonlar ile çalışılmış olsa da Heerwegh (2014) ile paralellik göstermektedir. Bilgilendirici olmayan önseller özellikle küçük örneklemlerde faktör yüklerinin yüksek tahminlenmesine ve gücün düşmesine neden olabilir. Olduğundan farklı sonuçlar elde etmemek ve küçük örneklemlerde Bayes yaklaşımının tüm avantajlarından yararlanabilmek için iyi tanımlanmış önsellerin kullanılmasıoldukça önemlidir. Yanlış tanımlama sadece söz konusu parametreleri değil modelin diğer kısımlarını da etkileyebilir. Önseldeki faktör yükleri yanlış tanımlandığında sadece kestirimlerdeki faktör yükleri değil faktörler arası korelasyon da bu durumdan etkilenmiştir.

Maksimum olabilirlik ve Bayes kestirimleri birlikte incelendiğinde: Maksimum olabilirlik kestirimine dayalı DFA'nın aksine Bayes yaklaşımına dayalı DFA'nın faktör yüklerinin parametre kestirim yanlılığı, düşük faktör yüklerinde daha düşüktür. Bilgilendirici önsellerin doğru belirlenmesi durumunda Bayes ile yapılan kestirimler maksimum olabilirlik ile yapılan kestirimlerden daha az yanlı sonuçlar vermektedir. Varyans küçüldükçe kestirim hatası azalmaktadır. Bilgilendirici önsellerin doğru belirlenmesi durumunda 
25 kişilik örneklemde Bayes ile yapılan kestirimler maksimum olabilirlik ile yapılan kestirimlerden daha az yanlı faktörler arası korelasyonun parametre kestirim sonuçları vermektedir. Bayes yaklaşımına dayalı DFA, faktör yükünün düşük olduğu durumlarda, hem güçlü hem de zayıf faktörler arası korelasyonda 25 kişilik örneklemde maksimum olabilirliğe göre faktörler arası korelasyonun parametre kestirimlerini daha yansız yapmıştır. Düşük faktör yüklerinde, maksimum olabilirlik çok yüksek faktör yüklerinin hata kareler ortalaması değerleri verirken, Bayes yaklaşımına dayalı tekniklerin faktör yüklerinin hata kareler ortalaması değerleri düşüktür. Bilgilendirici $\mathrm{N}(0.40$, 0.01) Bayesin faktör yüklerinin hata kareler ortalaması değerleri tüm örneklem büyüklüklerinde ve güçlü ve zayıf faktörler arası korelasyon durumlarında sıfıra yok yakındır. Orta düzeyde faktör yükünün olduğu durumda maksimum olabilirlik ile yapılan kestirimler ile bilgilendirici olmayan önselin kullanıldığı Bayes kestiriminin hata kareler ortalaması değerleri yakın ve bilgilendirici Bayes kestirimlerinden düşükken, zayıf faktör yükünde bayes teknikleriye yapılan kestirimlerin hata kareler ortalaması değeri maksimum olabilirlik ile yapılan kestirimlerden yüksektir. Heerwegh'e (2014) göre küçük ile çok küçük örneklemler arasında, Bayes kestirimlerinin maksimum olabilirlik kestirimlerine göre daha iyi performans göstermesi beklenir. Fakat çok küçük örneklemlerde önsellerin etkisi artmaktadır. Bu nedenle önsellerin hatalı tanımlanması durumunun etkisinin değerlendirilmesi önemlidir. Helm ve arkadaşları (2017) yaptıkları çalışmada DFA'da farklı maksimum olabilirlik ile Bayes kestirimlerini karşılaştırmıştır. Her faktörde 3 madde yer alan, faktör yüklerinin 0.30 ve 0.70 olduğu ve faktör korelasyonlarının 0.20 , 0.50 ve 0.80 olduğu koşullarda, 3 faktörlü yapı incelenmiştir. Yakınsama oranının maksimum olabilirlik kestirimlerinde \%50'nin altında kaldığını, Bayes kestirimlerinde ise $\% 100$ 'e yaklaştığını, Bayes kestirimlerinin maksimum olabilirlik ile yapılan kestirimlerden daha az yanlı, karşılaştırılabilir ve yeterli düzeyde parametre kestirimleri verdiğini raporlamıştır. Hem gerçek veride hem de yaptıkları simülasyon çalışmasında Bayes kestirimleri daha iyi ve kullanışlı sonuçlar vermiştir.

Heerwegh (2014) de çalışmasında bu çalışma sonuçlarına paralel olarak; orta ve düşük faktör yüklerinde bilgilendirici olmayan önsellerin kullanıldığ Bayes kestiriminde bile faktör yükü azaldıkça hata kareler ortalaması değerleri maksimum olabilirlik kestirimine göre daha düşüktür. Doğru tanımlanmış bilgilendirici önseller durumunda, Bayes DFA ile yapılan kestirimler 
maksimum olabilirlik DFA ile yapılan kestirimlerden önemli derecede daha düşük hata kareler ortalaması sonuçları vermiştir ve varyans küçüldükçe hata kareler ortalaması değeri azalmaktadır. Küçük örneklemlerde, orta düzey faktör yüklerinde, yanlış tanımlanmış önselli Bayes teknikleri bile maksimum olabilirlik kestiriminden daha iyi sonuçlar vermiştir. Yüksek faktör yükünün olduğu durumda maksimum olabilirlik kestirimi ve bilgilendirici olmayan önsellerin kullanıldığı Bayes kestiriminde yakın hata kareler ortalaması değerlerine sahiptir. Örneklemin 50 ve 25 olduğu durumda bilgilendirici olmayan önsellerin kullanıldığı Bayes kestiriminin hata kareler ortalaması değerleri maksimum olabilirlik ile yakın sonuçlar vermiştir. Bilgilendirici önsellerin yanlış belirlendiği durumda Bayes kestiriminin hata kareler ortalaması değerlerinin maksimum olabilirlik kestiriminden daha yüksek olduğu raporlanmıştır.

Bayes DFA ile yapılan kestirimler incelendiğinde, özellikle örneklem küçüldükçe, bilgilendirici önsellerin kullanıldığı durumlarda yapılan analizlerin gücü maksimum olabilirlik ile yapılan analizlerin gücünden yüksektir. Bilgilendirici olmayan önsellerin kullanıldığı durumlarda gücün hem bilgilendirici bayesin hem de maksimum olabilirlik kestiriminin kullanıldığı durumlardan düşük olduğu görülmektedir. Bunun nedeni olarak yanlış belirlenen önsellerin; faktör yüklerinin gerçek değerlerinden düşük, faktörler arası korelasyonların gerçek değerlerinden yüksek kestirilmesine neden olması olabilir. Bu sonuçlar Heerwegh (2014) ile paralellik göstermektedir.

Muthen ve Muthen (2002) her faktörde 5 madde bulunan, faktör yüklerinin 0.80 , faktör korelasyonunun 0.25 olduğu 2 faktörlü yapıda maksimum olabilirlik kestirimine dayalı DFA'da 0.81 güç için gerekli minimum örneklem büyüklüğünün 150 kişi olduğunu raporlamıştır. Bu çalışmada faktörler arası korelasyonun 0.30 olduğu durumda 100 kişilik örneklem büyüklüklerinde güç yaklaşık 0.60, 200 kişilik örneklem büyüklüklerinde güç yaklaşık 0.90 olarak hesaplanmıştır. düşük faktörler arası korelasyon durumunda maksimum olabilirlik kestiriminin gücü örneklem büyüklügü arttıkça yükselmektedir. Wolf ve arkadaşları (2013) ise faktörler arası korelasyonun bu çalışma ile aynı olduğu, her faktörde 3 madde bulunan, 2 faktörlü yapıda maksimum olabilirlik kestirimine dayalı DFA'da faktör yükleri yüksek olduğunda gereken minimum örneklem büyüklügünün azaldığını (0.50 ile 0.80 arasında kişi sayısında 2.5 kat fark oluşmaktadır) raporlamıştır. Ancak yanlılık ve hatada sıkıntı olmasa bile gücün düşük olabileceğini, bazı koşullarda 
ise güç yeterli düzeyde olsa bile yanlılık ve hata ile ilgili problemler olabileceğini, bu değerlerin birlikte ele alınması gerektiğini raporlamıştır.

Örneklem büyüklüğü arttıkça her teknikte faktör yüklerinin ve faktörler arası korelasyonun hata kareler ortalaması değeri düşmüştür. Faktörler arası korelasyonun güçlü ya da zayıf olması Bayes yaklaşımına dayalı tekniklerde de faktör yüklerinin hata kareler ortalamasını farklılaştırmamıştır. Faktör yükünün yüksek ve orta düzeyde olduğu durumlarda maksimum olabilirlik kestiriminde faktörler arası korelasyonun hata kareler ortalaması Bayes tekniklerinden düşükken, zayıf faktör yükünde hata kareler ortalaması değerinin Bayes tekniklerinden daha yüksek olduğu görülmektedir. Helm, (2017) yaptıkları çalışmada DFA'da hem maksimum olabilirlik ile hem de Bayes ile yapılan kestirimlerde örneklem büyüklüğü arttıkça kestirimlerin daha doğru yapıldı̆̆ını raporlamıştır.

\section{Öneriler}

$\mathrm{Bu}$ çalışmada her bir analiz için 1000 yineleme gerçekleştirilmiştir. Sonraki çalışmalarda daha kararlı sonuçlar elde edilene kadar replikasyon sayısı arttırilabilir.

Sonraki çalışmalarda, seçkisiz olarak seçilen birden fazla başlangıç değeri (seed - bir benzetimi her yaptığımızda aynı sonucu elde etmek için yazdı̆̆ımız rasgele seçim için başlangıç değeri) kullanılarak çalışmanın kararlılığı için elde edilen sonuçlar karşılaştırılabilir. Bu öneri Muthen ve Muthen (2002; 2009) tarafından da yapılmıştır.

Bu çalışmada iki faktörlü model ele alınmıştır. Bir faktörlü model veya çok faktörlü model (3 ve üzeri) ele alınarak model karmaşıklaştı̆̆ında (madde ve faktör sayısı fazla, faktör yükleri eşit olmayan vb.) maksimum olabilirlik ve Bayes kestirim iyiliği karşılaştırmalı olarak incelenebilir.

İleride yapılacak araştırmalarda; farklı dağılım tiplerinde, farklı veri tiplerinde, kayıp veri koşullarında, farklı modellerde maksimum olabilirlik ve Bayes kestirimleri karşılaştırılabilir. 


\title{
EXTENDED ABSTRACT
}

\section{What is the Required Sample Size for Confirmatory Factor Analysis?: Bayesian Approach and Maximum Likelihood Estimation}

\author{
Gizem Uyumaz - Gözde Sirganc1 \\ Giresun Universtiy, Yozgat Bozok University
}

Traditionally althought structural equation modelings (SEM) have traditionally been estimated in the frequentist framework with maximum likelihood estimation (MLE), Bayesian estimation is becoming increasingly popular. Bayesian statistics are based on Bayes' principle of conditional probabilities. The Bayesian approach is to estimate the posterior distributions by multiplying the prior distributions and likelihood distibution. BSEM has a number of advantages in comparison to using a frequentist estimation technique, such as MLE. First of all structural equation modelings based on Maximum likelihood estimation (ML-SEM) relies on large sample theory, and it is consequently often recommended to use it only in large samples (e.g. $\mathrm{N}=200$ or more). In smaller samples, ML-FA can run into problems such as model non-convergence, negative residual variances). Bayesian structural equation modeling (BSEM) does not rely on large-sample theory, which leads to the less bias with small sample sizes and may therefore be useful in studies that rely on smaller sample sizes. One advantages of Bayesian approaches is that allow to incorporate prior knowledge into the analyses instead of testing essentially the same null hypothesis over and over. In BSEM, researchers can provide a diffuse prior (large variance) distribution or an informative prior (small variance) distribution for a given parameter. A diffuse prior leads to the posterior distribution of the parameter being determined almost entirely from the data, where an informative prior leads to the posterior distribution of the parameter being a combination of the prior information and the data. The degree of informativeness and sample size effect paramater estimations of posterior distribution. In BSEM, when a diffuse prior (large variance) is used, the resulting mean estimates of the posterior distribution are often close to estimates obtained from MLE. The use of diffuse priors, along with large sample sizes, 
allows the likelihood to contribute a large portion of the information to the formation of the posterior distribution. In contrast, As sample sizes get smaller, the prior becomes more informative, the posterior becomes more influenced by the prior. In this respect, determining the appropriate prior distributions to be used in small samples is of importance to obtain unbiased estimations. The other advantages of using Bayesion estimation is about model identified. Traditional estimation methods require a model to be identified. For example, it is impossible in covariance based methods to estimate a CFA (confirmatory factor analysis) model in which all cross-loadings are free parameters. Bayesian estimation allows researchers to estimate non-identified models if the prior parameter distributions sufficiently constrains their values. For example, it is possible to estimate CFA models with cross-loadings that are expected to be approximately zero. Such models are argued to be more appropriate in expressing a researcher's theoretical expectations about cross-loadings. In the litrature, some simulation studies have already been undertaken to evaluate the performance of Bayesian CFA. However, there has been no study to evaluate model performance in specific situations such as very small samples.

The primary aim of this study is to prepare an easily accessible resource about the sample size necessary for researchers working in the fields of social sciences and educational sciences to obtain appropriate results in confirmatory factor analysis. The other aim of the study is to determine the prediction bias, mean square error and statistical power of the predictions obtained by the confirmatory factor analysis based on Bayesian approach using informative and non-informative a priori in small samples under various conditions, different factor loadings and correlation conditions between factors. determination.

The paper then shows the relative performance of Bayesian CFA as compared to ML-CFA for two-factor model with 3 indicators for each factor. The simulation conditions of research are four levels for small sample size $(\mathrm{N}=200$, $\mathrm{N}=100, \mathrm{~N}=50$, and $\mathrm{N}=25)$; diffuse $\mathrm{N}(0, \infty)$ and small variances $[\mathrm{N}(0.4,0.05)$ ve $\mathrm{N}(0.4,0.01)]$ of prior distrubution; three levels for the standardized factor loadings represented, respectively, high, moderate and low (.80, .60, and .40) and two level for the factor correlation represented week and strong $(.30, .50)$. There are 96 Monte Carlo simulation condition in this study. This paper will assess the quality of the analysis results on 3 criteria: Percentage parameter 
bias; Mean Squared Error ( MSE ); Statistical power in the model estimation. MPlus version 7 was used for monte carlo simulation.

ML-CFA leads to factor loading estimates which are close to the population values when the population factor loadings are moderate $(0.60)$ or high (0.80). With weak factor loadings (0.40), the estimates are biased further, especially at (very) small sample sizes ( $\mathrm{N}=50$ or less). In contrast to ML-CFA, Bayesian CFA performs well at weak factor loadings (0.40). Especially the informative priors perform well, and this at all sample sizes and also Bayesian CFA performs less well when the informative priors are miss specified. When using ML-CFA, the MSE increases with decreasing factor loadings. The MSE also decreases with increasing sample sizes. Bayesian CFA performs better than ML-CFA when the factor loadings are weak (0.40), even with a diffuse prior. ML-CFA leads to factor correlation estimates which are close to the population values when the population factor loadings are moderate $(0.60)$ or high (0.80). With weak factor loadings (0.40), the estimates are biased upwards, especially at (very) small sample sizes ( $\mathrm{N}=50$ or less). Bayesian CFA perform setter than ML-CFA at low factor loadings (0.40), especially at smaller sample sizes. Also, A diffuse prior leads to an under estimation of the factor correlation, while an informative prior leads to an over estimate. When investigating the results of statistical power of the ML-CFA, higher sample sizes and higher factor correlation yield higher statistical power. Bayesian CFA does better than ML-CFA at lower sample sizes, if the priors on the factor loadings are informative. While ML-CFA runs into problems at low sample sizes and weak to moderate factor loadings, Bayesian CFA consistently runs without errors.

\section{Kaynakça / References}

Anderson, J. C., ve Gerbing, D. W. (1984). The effect of sampling error on convergence, improper solutions, and goodness-of-fit indices for maximum likelihood confirmatory factor analysis. Psychometrika, 49(2), 155-173.

Asparouhov, T., ve Muthén, B. (2010). Bayesian analysis using Mplus: Technical implementation. Los Angeles, CA: Muthén \& Muthén.

Bandalos, D. L. (2006). The use of Monte Carlo studies in structural equation modeling research. In R. C. Serlin (Series Ed.), G. R. Hancock, ve R. O. Mueller (Vol. Eds.), Structural equation modeling: A second course (s. 385-462). Greenwich, CT: Information Age. 
Bentler, P. M., ve Chou, C. P. (1987). Practical issues in structural modeling. Sociological methods $\mathcal{E}$ research, 16(1), 78-117.

Bollen, K. A. (1989). A new incremental fit index for general structural equation models. Sociological methods \& research, 17(3), 303-316.

Boomsma, A. (1985). Nonconvergence, improper solutions, and starting values in LISREL maximum likelihood estimation. Psychometrika, 50(2), 229-242.

Cohen, J. (1988). Statistical power analysis for the behavioral sciences (2nd ed.). Hillsdale, N J: Erlbaum.

Cohen, J., \& Cohen, P. (1983). Applied multiple regression/correlation analysis for the behavioral sciences. Hillsdale, NJ: L. NJ Eribaum.

Comrey, A. L., ve Lee, H. B. (1992). A first course in factor analysis, (2nd Edition). Hillsdale, NJ: Lawrence Erlbaum Associates, Inc.

De Winter, J. C. F, Dodou, D., and P. A. Wieringa (2009). Exploratory factor analysis with small sample sizes. Multivariate Behavioral Research, 44, 147-181.

Goodwin, L. D. (1999). The role of factor analysis in the estimation of construct validity. Measurement in Physical Education and Exercise Science, 3(2), 85-100.

Hair, J. F. Jr. , Anderson, R. E., Tatham, R. L., ve Black, W. C. (1998). Multivariate data analysis, (5th Edition). Upper Saddle River, NJ: Prentice Hall.

Hancock, G. R., ve French, B. F. (2013). Power analysis in structural equation modeling. In G. R. Hancock \& R. O. Mueller (Eds.), Quantitative methods in education and the behavioral sciences: Issues, research, and teaching. Structural equation modeling: A second course (s. 117-159). IAP Information Age Publishing.

Heerwegh, D. (2014). Small sample Bayesian factor analysis. Phuse. Retrieved from http://www. lexjansen.com/phuse/2014/sp/SP03. Pdf adresinden erişilmiştir.

Helm, J. L., Castro-Schilo, L., ve Oravecz, Z. (2017). Bayesian versus maximum likelihood estimation of multitrait-multimethod confirmatory factor models. Structural Equation Modeling: A Multidisciplinary Journal, 24(1), 17-30.

Hu, L. T., ve Bentler, P. M. (1999). Cut-off criteria for fit indexes in covariance structure analysis: convenfional criteria versus new alternafives. Structural equafion modelling. Ref. Bibliográfica, 6(1), 1-55..

Jackson, D. L. (2001). Sample size and number of parameter estimates in maximum likelihood confirmatory factor analysis: A Monte Carlo investigation. Structural Equation Modeling, 8, 205-223.

Jöreskog, K. G., ve Sörbom, D. (1996). LISREL 8 user's reference guide. Uppsala, Sweden: Scientific Software International. 
Kelley, K., ve Maxwell, S. E. (2003). Sample size for multiple regression: Obtaining regression coefficients that are accurate, not simply significant. Psychological Methods, 8 , 305-321.

MacCallum, R. C., Widaman, K. F., Zhang, S., ve Hong, S. (1999). Sample size in factor analysis. Psychological methods, 4(1), 84.

Maxwell, S. E., Kelley, K., ve Rausch, J. R. (2008). Sample size planning for statistical power and accuracy in parameter estimation. Annual review of psychology, 59.

Muthén, B., ve Asparouhov, T. (2012). Bayesian structural equation modeling. a more flexible representation of substantive theory. Psychological methods, 17(3), 313.

Muthén, L. K., ve Muthén, B. O. (2002). How to use a Monte Carlo study to decide on sample size and determine power. Structural equation modeling, 9(4), 599-620.

Nevitt, J., ve Hancock, G. R. (2004). Evaluating small sample approaches for model test statistics in structural equation modeling. Multivariate Behavioral Research, 39(3), 439-478.

Satorra, A., ve Saris, W. E. (1985). Power of the likelihood ratio test in covariance structure analysis. Psychometrika, 50(1), 83-90.

Song, X. Y., ve Lee, S. Y. (2012). Basic and advanced Bayesian structural equation modeling: With applications in the medical and behavioral sciences. Chichester, England:Wiley.

Stevens, J. (2002). Applied multivariate statistics for the social sciences. Mahwah, NJ: Lawrence Erlbaurn Associates.

Tanaka, J. S. (1987). How big is big enough?": Sample size and goodness of fit in structural equation models with latent variables. Child development, 134-146.

Van de Schoot, R., Kaplan, D., Denissen, J., Asendorpf, J. B., Neyer, F. J., ve Van Aken, M. A. (2014). A gentle introduction to Bayesian analysis: Applications to developmental research. Child development, 85(3), 842-860.

Wolf, E. J., Harrington, K. M., Clark, S. L., ve Miller, M. W. (2013). Sample size requirements for structural equation models: An evaluation of power, bias, and solution propriety. Educational and psychological measurement, 73(6), 913-934.

Yu, C. Y., ve Muthén, B. O. (2002). Evaluation of model fit indices for latent variable models with categorical and continuous outcomes. Los Angeles: University of California, Los Angeles, Graduate School of Education and Information Studies. Graduate School of Education and Information Studies. 
Kaynakça Bilgisi / Citation Information

Uyumaz, G. ve Sırgancı, G. (2020). Doğrulayıcı faktör analizi için gerekli örneklem büyüklüğü kaç kişidir? : Bayes yaklaşımı ve maksimum olabilirlik kestirimi. OPUS-Uluslararası Toplum Araştırmaları Dergisi, 16(32), 5302-5340. DOI: 10.26466/opus.826895 